\title{
Az Alföld metamorf aljzata: a köztes tömegtól a tarka mozaikig
}

\author{
M. TóTH Tivadar ${ }^{1}$, FISER-NAGY Ágnes ${ }^{1}$, KONDOR Henrietta ${ }^{1}$, MoLNÁR Lászlón ${ }^{1,2}$, \\ SCHUBERT Félix ${ }^{1}$, VARGÁNÉ Tóth Ilona ${ }^{3}$, ZACHAR Judit ${ }^{1}$ \\ ${ }^{1}$ Szegedi Tudományegyetem, Ásványtani, Geokémiai és Kőzettani Tanszék, Egyetem u. 2., 6721, Szeged, \\ ${ }^{2}$ Rhk Kht., \\ ${ }^{3} \mathrm{MOL}$ Nyrt \\ mtoth@geo.u-szeged.hu, agnesfisernagy@gmail.com, kondor.henrietta@gmail.com, molnar.laszlo@rhk.hu, \\ schubert@geo.u-szeged.hu, IlonaToth@MOL.hu,dyfen75@yahoo.co.uk
}

\section{The metamorphic basement of the Great Hungarian Plain: from Zwischengebirge towards a variegated mosaic}

Abstract

As a result of the increasing amount of petrological information which has been gathered over the last six decades, the structural image of the metamorphic basement of the Great Hungarian Plain has changed significantly. The old model of a homogeneous and rigid "Zwischengebirge" has been replaced by a variegated mosaic of mobile crustal blocks. These blocks took an active part in all essential tectonic motions from the time of the Variscan orogeny. In this paper it is concluded that the metamorphic evolution of rock bodies can be represented by 8 study areas across the Great Hungarian Plain: namely, Jánoshalma, Kiskunhalas-Tázlár, Szank, Csólyospálos-Kömpöc, Szeghalom, Mezősas-Furta, Dorozsma and Algyő. Besides their lithological characteristics, the spatial relationship of the diverse basement blocks is discussed based on a combined evaluation of petrological and well-log data.

The results suggest that a few typical lithological and structural patterns can be referred to in order to characterize the metamorphic basement of the Great Hungarian Plain. In the Kiskunhalas area the lowermost unit is dominated by an orthogneiss block, above which a low metamorphic-grade phyllite block appears alongside a thick mylonite zone. The low-angle ductile shear zone follows a dip, close to the north. Three blocks of different $P-T$ evolution types constitute the Szank, the Szeghalom and the Mezósas-Furta areas. The orthogneiss, the garnet-sillimanite-biotite gneiss and the amphibolite-dominated realms are separated by shear zones, as indicated by brittle, deformed tectonic rocks, cataclasites and fault breccias. Based on well-log interpretations, these overthrusts dip to the south-west and probably belong to the Alpine nappe system. The thick overthrust zone - which separates blocks of different types of metamorphic evolution in the Dorozsma area - is also interpreted as part of the Cretaceous nappe system. Here and there in the neighbouring Algyó area, the structure is further complicated by tectonic zones which arose due to the formation of a metamorphic core complex resulting from the subsidence of the Pannonian Basin during the Neogene. Finally, the existing blocks of different metamorphic and post-metamorphic evolutionary backgrounds build-up the basement in the southern part of the Great Hungarian Plain.

All the structural patterns identified here serve as a firm basis for defining the lithostratigraphic units throughout the metamorphic basement. As these units are extremely heterogeneous with respect to their petrology and structure, they must be defined as complexes, following the proper terminology.

Keywords: Great Hungarian Plain, metamorphic basement, P-T-path, shear zone, structural pattern

Összefoglalás

A hozzáférhető fúrómaganyag mennyiségének növekedésével, valamint a kőzettani módszerek fejlődésével párhuzamosan az elmúlt évtizedekben alapvetően megváltozott a modellünk az Alföld metamorf képződményekből álló medencealjzatáról. A korábbi egyveretú, statikus aljzat kép helyét egy nagyon eltérô metamorf fejlődéstörténetű egységekből álló, tarka mozaik vette át. Ez a kőzettani sokszínúség az 1960-as évekig feltételezett merev, ,,köztes tömeg” elképzeléssel szemben a variszkuszi orogenezis óta a szerkezeti mozgásokban aktív szerepet játszó metamorf litoszféra dinamikájának eredményeként alakulhatott ki. Dolgozatunkban nyolc aljzati mintaterületen mutatjuk be a felépítő fő metamorf képződményeket, azok evolúcióját, valamint térbeli kapcsolatrendszerüket. A vizsgált területek Jánoshalma, Kiskunhalas-Tázlár, Szank, Csólyospálos-Kömpöc, Szeghalom, Mezősas-Furta, Dorozsma és Algyő. A kőzetblokkok térbeli helyzetének rekonstrukciója során a részletes petrológiai elemzés mellett négy esetben lyukgeofizikai információt is integráltunk a modellekbe. 
Az eredmények alapján az Alföld metamorf aljzatát a vizsgált területeken különböző szerkezeti mintázatok jellemzik. Kiskunhalason alsó szerkezeti helyzetú ortogneisz-domináns egység fölött széles, különböző kiindulási kőzettípusok deformációjával keletkezett milonitzóna, majd azt követően kis metamorf fokú fillit következik. Az eltérő fejlődésú egységeket elválasztó képlékeny nyírási zóna lapos szögú, közel északi dőlésú. A Szank, a Szeghalom, valamint a Mezősas-Furta területeket három, eltérô metamorf $P-T$ (nyomás-hőmérséklet) fejlődést mutató egység építi fel, melyeket töréses deformációval jellemzett kataklázit zónák választanak el egymástól. Ezek a DNy-i dólésú nyírási zónák feltételezhetően az alpi takarórendszer valamely egységéhez tartoznak. Szintén kréta korú feltolódásként értelmezzük a Dorozsma területen felismert aljzati blokkokat elválasztó széles kataklázit zónát. Itt, valamint a szomszédos Algyő területen ezt a felépítést felülírják a medence kainozoos keletkezésével szinkron metamorf magkomplexum kialakulásához köthető szerkezetek. Mindezek komplex eredményeként jelenleg inkompatibilis metamorf fejlődésú egységek alkotják az Alföld déli részének metamorf aljzatát.

A különböző mintaterületeken azonosított szerkezeti mintázatok megfelelő alapot biztosítanak az Alföld metamorf aljzatának litosztratigráfiai újragondolása során is. Így az egyes, litológiailag önmagukban is rendkívül heterogén egységeket (komplexumokat) célszerú ezen mintázatok alapján definiálni és lehatárolni.

Tárgyszavak: Alföld, metamorfaljzat, P-T-út, nyírási zóna, szerkezeti mintázat

\section{Bevezetés}

Az Alföld metamorf medencealjzatának felépítésével, szerkezetével, fejlődéstörténetével kapcsolatos nagyléptékú modelljeink hátterét a szeizmikus értelmezések biztosítják. Ezen vizsgálatok alapján jelölhetók ki azok a különbözó rendú szerkezeti zónák, melyek az aljzatot egymás melletti részegységek rendszereként definiálják. A kutatások célja a kezdetek óta kettős; a földtörténeti értelmezés mellett kiemelt feladat az aljzat szerepének minél pontosabb tisztázása a medence hidrodinamikájában, mindenekelôtt a szénhidrogének migrációjában, tárolásában. A nemzetközi összehasonlításban is különleges, nagyszámú repedezett metamorf szénhidrogén-rezervoár felismerésének eredményeként mára jelentős számú mélyfúrás harántolta az aljzati metamorf képződményeket, lehetôvé téve azok kőzettani vizsgálatát is. Az elmúlt mintegy 50 évben a szisztematikus petrográfiai kutatások, mindenekelőtt SZEPESHÁZY Kálmán (1966, 1971, 1973a, b, 1979), SZEDERKÉNYI Tibor (1984, SZEDERKÉNYI et al. 1991), ÁrKAI Péter (1991, 1993, 2001; ÁrKAI et al. 1998, 2000; Horváth \& ÁrKaI 2002), LELKESNÉ FelVÁRI Gyöngyi (LeLKES-FeLVÁRI et al. 2003, 2005), valamint az OKGT/MOL munkatársainak (BALÁzs et al. 1985, 1986; CSEREPESNÉ MEsZÉNA 1978, 1983, 1985, 1986; SzILI-GyÉMÁNT 1986) munkája eredményeként folyamatosan pontosodott az aljzat metamorf képződményeiről, azok térbeli kapcsolatrendszeréről alkotott kép. A kutatásnak ebben a szakaszában a fó kőzettípusok azonosítása mellett egyedi minták termobarometriai és geokronológiai elemzése, s ezen adatok rendszerbe foglalása volt a fó feladat.

Az eredmények teljes aljzatra történő részletezése nélkül kiemelendő az a nagyon koherens kép, mely - a szeizmikus vizsgálatokkal összhangban - kijelölte és jellemezte kôzettípus, protolit kőzetkémia, valamint $P-T-t$ (nyomás, hőmérséklet, idô) értelemben a metamorf aljzat fó egységeit, azokat hol komplexumnak, terrénumnak, formációnak nevezve a kor litosztratigráfiai elvárásainak megfelelóen. Ezek az egymásra épülő, egyre inkább részletgazdag modellek biztosították a megfelelôen stabil alapot az elmúlt mintegy három évtized vizsgálataihoz.
Ezzel együtt a jelenlegi kutatások munkahipotézise egy, a korábban elképzeltnél jóval heterogénebb felépítésú metamorf aljzatot feltételez. A geokronológiai adatok, bár számottevő lokális változékonyságot mutatva, lényegében egységesen variszkuszi korú maximális metamorfózisra utalnak a teljes területen. Elenyésző információval rendelkezünk ugyanakkor a posztorogén exhumáció viszonyairól. Másrészt számos koradat sejteti, hogy a döntôen metamorf képződményekből álló litoszféra aktívan részt vett a jura riftesedés, majd a kréta takaróképződés folyamataiban, s ezek következtében a korábban egységes metamorf tömeg lapos szögú nyírási zónák mentén feldarabolódott, összességében számottevő mértékû horizontális és vertikális átrendeződést eredményezve. Ezen mozgások mértékét és pontos helyszíneit nem ismerjük. Tovább bonyolítja a képet az aljzat mára elméletileg megismert kitüntetett szerepe a Pannon-medence kialakulásában (TARI et al. 1992); a jelentôs oldalelmozdulásos zónák mellett szeizmikus értelmezések és geokronológiai adatok igazolják, hogy a medence jól definiált részterületein a középső miocén során metamorf magkomplexumok keletkeztek több km-es horizontális és vertikális átrendeződést eredményezve a metamorf litoszférában (PosGAY et al. 1996, TARI et al. 1999). A posztorogén exhumáció, jura extenzió, kréta kompresszió, neogén oldalelmozdulás és extenzió mint legfontosabb, ugyanakkor részleteiben alig ismert folyamatok együttes hatásának eredményeként feltételezhető, hogy jelenleg akár kis területen belül is inhomogén felépítésú és fejlődésú kôzetblokkok alkotják az aljzatot, melyek között a térbeli korreláció lehetôsége a korábban feltételezettnél jóval korlátozottabb lehet.

Mindezek miatt az utóbbi évtizedek fố kutatási feladataként a fúrómaganyag teljes kőzettani reambulációját túztük ki annak érdekében, hogy képesek legyünk a kis területekre vonatkozó heterogenitások felismerésére, kôzettani és geodinamikai értelmezésére az összes elérhető információ integrálásával.

A jelen tanulmány célja röviden bemutatni az Alföld metamorf aljzatának azon részterületeit, melyek esetében az elmúlt évtizedek reambulációs munkájának eredményeként érdemi előrelépés történt. A vizsgálatoknak, természetesen, 
fontos következményei vannak az aljzati repedezett fluidum (mindenekelőtt szénhidrogén) -rezervoárok migrációs és tárolási viselkedésével kapcsolatban is. Ezeket a vonatkozásokat a jelen tanulmány nem érinti.

\section{Módszerek}

Metamorf kőzetek petrográfiai vizsgálatának fő feladata a kőzetre jellemző fejlődéstörténet kvalitatív rekonstrukciója. Ez jelenti egyrészt a fố metamorf eseményt jellemzô ásványparagenezis azonosítását, másrészt a pre-, szin- és posztkinematikus szöveti elemek felismerését, jellemzését, rendszerbe foglalását. A mikroszkóp alatt azonosított egyensúlyi szöveti elemek sorozata alapján nyílik mód a továbbiakban a különböző kvantitatív termobarometriai módszerek alkalmazásával a fejlődési út fizikai ( $P-T-d$ - nyomás, hőmérséklet, deformáció) körülményeinek számszerúsítésére.

A fejlődéstörténet rekonstrukciója mellett munkánk célja az egyes aljzatblokkokat alkotó kőzettestek fő kőzettípusainak klasszifikációja, majd az azonos típusok térbeli kiterjesztése alapján a kőzetvázak 3D modelljeinek megalkotása. A litológiai alapú osztályozás bázisát képező pozitív és negatív kritériumok rendszerét elsődlegesen a fúrások által feltárt kôzetminták részletes szöveti jellemzése teremtheti meg; a kőzettípusok megkülönböztetése egyaránt lehetséges egyes szöveti bélyegek rendszeres megjelenésével és mások következetes hiányával. Ezen szöveti kritériumok alapján biztosítható az egyes kőzetcsoportok közötti diszkrimináció, ami a csoporton belüli maximális hasonlóság, valamint csoportok között maximális heterogenitás egyidejû meglétét feltételezi. Kőzetek valamely csoportját akkor tekinthetjük azonosíthatónak, ha a rá jellemző szöveti bélyegek mellett a többi csoporttól való különbözőség jellegzetességeit is definiáljuk. A litológiai osztályozás kritériumrendszere alapján - a maggal fel nem tárt intervallumokra lehetőség nyílik a kőzettestek lyukgeofizikai alapú definiálására, így a térbeli kiterjesztés pontosítására is.

\section{Termobarometria - a $\boldsymbol{P}-\boldsymbol{T}$ evolúció rekonstrukciója}

A termobarometriai számítások célja a petrográfiai vizsgálatok során felvázolt kvalitatív $P-T$-út egyes állomásainak számszerúsítése; adott bizonytalanságú $P_{0}-T_{0}$ értékpárok alapján a kőzetet jellemző kvantitatív $P-T$-út felvázolása. A termobarometriai számítások alapja az a feltételezés, miszerint a kőzet az adott metamorf fokon egyensúlyba jutott valamely jellemzőjét a posztkinematikus átalakulás során megőrizte, s ez alapján a metamorf átalakulás fizikai körülményei - adott bizonytalanság mellett - rekonstruálhatók. A legáltalánosabban az egykori stabil ásványparagenezis vagy annak egyes reliktumfázisai utalnak a metamorfózis viszonyaira. Gyakoriak a szöveti reliktumok, ahol az egykori szemcsék mérete, alakja, térbeli elrendeződése, kristályszerkezete alapján következtethetünk a fejlődés egyes állomásaira. Esetenként az egyensúlyi elemeloszlás is megőrződik a koegzisztens ásványokban, ezáltal kalibrált ásványreakciók használatát téve lehetôvé.

A különböző mértékben megőrződött, eltérô litológiájú kőzetek esetén más-más termobarometriai becslési eljárás alkalmazása indokolt, melyek elméleti háttere, adatigénye, bizonytalansága alapvetően eltér egymásétól. A számos kísérleti kőzettani munka ellenére termobarometriai számításaink minden esetben hibával terheltek. A lehetséges hibák egy része jelentôsen csökkenthetô önellentmondás-mentes termodinamikai adatbázisok alkalmazásával. Az elmúlt évtizedekben megjelent termométerek és barométerek kielégítik ezt a feltételt, hiszen vagy a többször kiegészített BERMAN (1988), vagy a Powell \& Holland (1985), Holland \& Powell $(1985,1990,1998)$ féle adatbázisok alapján kerültek kalibrálásra.

\section{Kalibrált termométerek, barométerek}

Megőrződött ásványparagenezisek esetén az elmúlt évtizedekben kalibrált nagyszámú termobarométer alkalmazható, feltételezve, hogy a koegzisztens fázisok elérték az ioncsere egyensúlyt, ami a későbbi folyamatok során sem íródott felül. Mindazonáltal, ezen eljárások alkalmazhatósági kritériumainak, s különösen az egyensúly megőrződésének igazolása különös körültekintést igényel.

\section{Paragenezis modellezés}

Bár a termobarometriai számítások legpontosabb útja a kalibrált termométerek és barométerek alkalmazása, a legtöbb kőzettípus esetén, megfelelő egyensúlyi ásványtársaság hiányában a módszer nem alkalmazható. Továbbá, ezen eljárások eredménye is igen sok bizonytalansággal terhelt, melyek eredőjeként a számított hiba olykor meglepően nagy lehet (Lieberman \& Petrakakis 1991, KoHN \& Spear 1991). Számos esetben, bár egyértelmú szöveti bizonyítékok adhatók valamely metamorf ásványtársaság létére, az egykor feltételezhetôen kialakult kémiai egyensúly az azóta lejátszódott posztmetamorf folyamatok eredményeként megbomlott. A petrográfiai vizsgálatok eredményeként kirajzolódó kvalitatív metamorf fejlődés ugyanakkor ezekben az esetekben is megfelelő alapot biztosíthat a $P-T$-út numerikus jellemzésére. Igen nagy a megfelelő termodinamikai számításokat alkalmazó, fontos részleteiben mégis eltérő termobarometriai modellező rendszerek száma. A továbbiakban mindezek közül két megközelítést, a TWQ (BERMAN 1991), valamint a DoMINO/THERIAK (DE CAPITANI 1994) modellező rendszereket fogjuk használni.

A TWQ alapfeltevése, hogy a modellezett ásványtársaság valamely metamorf $P-T$-n teljes egyensúlyba jutott, $\mathrm{s}$ azóta az egyes fázisok összetétele nem változott. Ekkor a paragenezist jellemző kémiai alrendszerben (megfelelő termodinamikai adatbázist alkalmazva) az összes algebrailag lehetséges egyensúlyi reakció helyzete meghatározható a $P-T$-síkban. Ideális feltételek mellett (pontosan ismert az egyes fázisok kémiai összetétele, valamint minden termodi- 
namikai és elegyedési jellemzőjük), a rendszerben felírható reakciók egyetlen pontban (az egyensúlyi $P_{0}-T_{0}$ pontban) metszik egymást. Az ettől való eltérés egyrészt utal arra, hogy a vizsgált kőzet elérte-e az egyensúlyt, illetve a posztmetamorf átalakulások során attól szignifikánsan eltért-e. Az egyensúlyi reakciók modellezhetôk az egyes fázisok összetételének pontos ismeretének hiányában is, ekkor célszerû a modellezést szélsô tagokra elvégezni (end-member reactions).

A Domino/TheriaK (DE CAPITANi 1994) modellező rendszer célja tetszóleges $P_{0}-T_{0}$ pont (vagy intenzív változók bármely más kombinációja) esetén az egyensúlyi ásványparagenezis számítása a vizsgált kőzet (vagy annak szövetileg egyértelmúen definiálható tartománya) teljes kémiai összetétele alapján. A modellezés során bármely $P_{0}-T_{0}$ pont esetén az adott kémiai rendszerben a használt termodinamikai adatbázis (pl. BERMAN 1988) alapján algebrailag lehetséges ásványparagenezisek közül az algoritmus a minimális Gibbs-energiájút tekinti stabilnak (DE CAPITANI \& BROwN 1987). Az így kapott fázisdiagram összevethető a mikroszkópi elemzések során megfigyelt paragenezissel, mind az egyes fázisok modális arányait, mind azok kémiai összetételét tekintve.

Polimetamorf kőzet vizsgálata esetén, amennyiben a kőzet a fejlődés egymást követô állomásait képviselő szöveti reliktumokat tartalmaz, azaz bizonyíthatóan nem jutott szöveti (s így kémiai) egyensúlyba, a kalibrált termobarométerek alkalmazása rendszerint hibás eredményhez vezet. Ebben az esetben is meghatározható ugyanakkor a kőzetben adott részterületek mint geokémiai domének kémiai összetétele az egyes ásványok összetétele és modális mennyisége alapján. Ekkor - feltételezve, hogy a kőzet lokálisan egyensúlyba jutott, s a relikt fázisok sorozata a kőzet $P-T$-fejlődését reprezentálja - a DOMINO/THERIAK modellezés iteratív ismétlésével a teljes kémiai összetétel és a stabil paragenezis számítása finomítható, és a modell eredménye a mikroszkópi megfigyeléssel konzisztenssé tehetô. Így, mivel a számítás minden $P_{0}-T_{0}$ pontban az adott kémiai összetétel esetén minimális Gibbs-energiájú ásványtársaságot eredményezi, a megközelítés rendszerint jól alkalmazható az egymást követő ásványtársaságok stabilitási tartományának becslése, $\mathrm{s}$ így a $P-T$-evolúció rekonstrukciója során (MEYRE et al. 1997, M. Tóth et al. 2000, KelsEY et al. 2004). Nem izokémikus metamorf átalakulások (fluidumtartalmú reakciók, metaszomatózis) esetén a $P-T$-tér vizsgálata helyett a megfelelően választott $T-X_{i}\left(P-X_{i}\right)$ tér modellezése lehet célravezető.

Ellentétben a kalibrált termobarométerek alkalmazásával, a DOMINo/THERIAK modellezés valamely $P_{0}-T_{0}$ pont helyett adott egyensúlyi ásványtársaság stabilitási tartományát számítja. Ezért az eredmény nem gaussi hiba típusú bizonytalansággal terhelt, hanem - mind a $T$, mind a $P$ vonatkozásában - intervallum típusú eredményt ad. Ez a robosztus megközelítés ugyanakkor jóval kevésbé érzékeny a termobarometriai számításainkat terhelő hibaforrásokra.

A továbbiakban mind a TWQ, mind a DOMINO/THERIAK típusú modellezés során BERMAN (1988) többször kiegészített termodinamikai adatbázisát használjuk.

\section{Szöveti termobarométerek}

Nagy kvarctartalmú metamorf kőzetek esetében gyakori az egymást érintő azonos típusú ásványszemcsék határán a kristályosodás és deformációtörténet hatásait tükröző szutúravonal kialakulása. Mivel az egyes szemcsék szabadenergiáját jelentős mértékben a szemcsehatár hossza (a szemcse felülete) határozza meg, polikristályos anyag ezen érték csökkentésére, s így egyenes határok elérésére törekszik. A folyamat a hőmérséklet emelkedésével egyre hatékonyabbá válik, ami nagy hőmérsékleten kialakult poligonális szövetek esetében közel egyenes, míg pl. kis hőmérsékletû nyírás esetén rendkívül tagolt, bonyolult lefutású szemcsehatárt eredményez (MASUdA \& FUJIMURA 1981). KRUHL \& NEGA (1996) polikristályos, eltérő hőmérsékleten rekrisztallizálódott kőzetekben hasonlították össze a kvarcszemcsék között kialakuló szutúravonal bonyolultságát, és ennek mértéke alapján termométert kalibráltak. Az eljárást kísérleti adatok alapján TAKAHASHI et al. (1998) finomították. A szemcsehatár olyan geometriai objektum, amely mérettartománytól függetlenül önmagához hasonló görbe, ennek megfelelően bonyolultságának mértékét KRUHL \& NEGA (1996) a szutúra fraktáldimenziójaként definiálják, s mérésére a MANDELBROT (1967) által bevezetett módszert ajánlják. Ennek lényege, hogy a mért, bonyolult görbét $r$ hosszúságú szakaszokból álló poligonnal közelítjük, s ekkor a különböző $r$ értékek mellett kapott $L(r)$ hosszúságokra igaz, hogy $L(r)=r^{1-D}$, ahol $D$ a keresett fraktáldimenzió értéke. Alacsony ( 1) dimenzióérték viszonylag sima szutúravonalat és ennek megfelelően nagy hőmérsékletet jelez, míg a hőmérséklet csökkenése tagolt görbét és magasabb dimenzióértéket eredményez.

A szemcsehatár geometriája mellett a metamorfózis fizikai körülményeire utaló legfontosabb szöveti bélyeg a szemcsék méreteloszlása. Igen régi az a megfigyelés, miszerint emelkedő hőmérséklettel azonos típusú ásványok szemcséi fokozatosan növekvő méretet vesznek fel (SPRY 1969). A szemcseméret-eloszlás különösen a feszültségmentes viszonyok között kialakuló poligonális szövetek esetén megbízható indikátora a metamorf hőmérsékletnek. KRUHL (2001) számításai szerint plagioklászból álló poligonális szemcsehalmazokban az átlagos szemcseátmérô a hőmérséklet lineáris függvénye, ami az 500-800 ${ }^{\circ} \mathrm{C}$ intervallumban szöveti alapú termométer kalibrálását tette lehetôvé. Az eljárás különösen alkalmas olyan nagy földpáttartalmú kőzetek termometriai vizsgálata során, melyek nagyon egyszerú ásványos összetétele egyéb módszerek használatát nem teszik lehetővé (pl. különböző kvarc- és földpátdomináns gneisztípusok).

\section{Kristályszerkezet alapú termobarométerek}

A diagenezis és a metamorf folyamatok során a szenes anyag számottevő átalakuláson megy keresztül, s szerkezet nélküli szerves anyagból rendezettebb grafit állapotba jut. A rendezettség mértéke monoton növekszik a metamorf fok és elsősorban a hőmérséklet növekedésével. A metamorfizálódó szenes anyag Raman-spektruma, ennek megfelelően, fo- 
lyamatosan változik a növekvő hőmérséklettel (WOPENKA \& PASTERIS 1993, Yui et al. 1996). Mivel a grafitosodás irreverzibilis folyamat, a grafit szerkezetét elsődlegesen a metamorf út során elért maximális hómérséklet határozza meg (BEYSSAC et al. 2002, BEYsSAC et al. 2004, AOYA et al. 2010), így a szenes anyag szerkezete érzéketlen a retrográd átalakulásokra is (WIEDERKEHR et al. 2011). A szenes anyag Ramanspektruma elsôrendû́ (1100-1800 $\mathrm{cm}^{-1}$ ) és másodrendú (2500-3100 $\left.\mathrm{cm}^{-1}\right)$ régiókból áll. Az elsôrendú régióban található a G (grafit) sáv, valamint az ún. D (,defect”) sávok, mely utóbbiak a grafit szerkezeti rendezetlenségére utalnak (TUINSTRA \& KoENIG 1970). A metamorf fok növekedésével a D csúcsok intenzitása csökken, a csúcsok folyamatosan elkeskenyednek, miközben a G csúcs intenzitása nő. A grafit Raman spektruma alapján számítható R1 (=D1/G) és R2 (=D1/[G+D1+D2]) paraméterek mindezek alapján a metamorf hőmérséklet függvényei, ami termométer kalibrálását teszi lehetővé. Így, pl. a BEYSSAC et al. (2002) által kalibrált egyenletét, mellyel a keletkezési hőmérséklet $\pm 50{ }^{\circ} \mathrm{C}$ pontossággal számítható a 330-650 ${ }^{\circ} \mathrm{C}$ intervallumban. RAHL et al. (2005) módosított termométere 100 és $700{ }^{\circ} \mathrm{C}$ között alkalmazható, majd AoYA et al. (2010) tovább finomították a becslési eljárást. Mindezen termometriai számítások során BEYSSAC et al. (2003) ajánlását követve a Raman-felvétel spektrális paramétereit Peak Fit 4.12 szoftverrel, Voightfüggvény illesztésével származtattuk.

Az ásványzárványok és az ôket bezáró gazdaásványok eltérő hőtágulási és kompresszibilitási tulajdonságai miatt a bezáródáskori $P$ és/vagy $T$ megváltozásának hatására, a $P$ $T$-út mentén a zárványok kristálytani paraméterei módosul(hat)nak. Ez a kismértékú változás az ásvány Raman-spektrumában a csúcspozíciók eltolódását okozza. A Ramanspektrumok paraméterei, valamint a zárvány és a gazdaásvány megfelelő termodinamikai adatai alapján feltételezett $T_{0}$ hőmérsékleten bezáródási nyomást (esetleg $P_{0}$ nyomáson bezáródási hőmérsékletet) becsülhetünk. Jelen dolgozatban gránátba zárt kvarcszemcsék esetén barometriai számítások céljából a "Thermoba-Raman-try” (KoHN 2014) eljárást alkalmaztuk.

\section{A petrológiai információ térbeli kiterjesztése}

Egy adott terület kialakulását leíró fejlődéstörténeti modell mellett a kőzettani kutatás fontos célja a felismert litológiai egységek térbeli viszonyának rekonstruálása, s így a 3D kőzetvázmodell megalkotása. Ez a folyamat célszerúen az információ bővítését jelenti a pontszerünek tekinthető kőzettani információtól a 3D térbeli modell irányába. A folyamat első lépése a részletes kőzettani $(P-T-d)$ információ alapján történő litológiai klasszifikáció, melynek során a lényegileg azonos fejlődésűnek tekinthető típusok meghatározása történik. Második lépésben a több litológiai típust harántolt fúrások alapján az egyes kőzettípusok relatív térbeli helyzetét célszerû́ tisztázni. Ennek eredményeként előáll az az ideális kőzetoszlop, amely vertikális 1D metszetben jellemzi a vizsgált területet. Az 1D modell kialakítását nagyban segítheti a lyukgeofizikai szelvények kiértékelése, feltéve, hogy az egyes litológiai típusok vagy a határukon megjelenô szerkezeti zónák fizikai tulajdonságaik, s így a jellemző szelvényképek alapján azonosíthatók. A fúrásonként rendelkezésre álló 1D modellek egyenközú vízszintes metszetei a horizontális 2D modellek síksorozatát eredményezik. Ezeken a térképeken a fúrásokra kiterjesztett kőzettani információ (a litológiai típus) pontbeli adatként jelenik meg, melyek homogén foltjai és határai klasszikus eszközökkel kijelölhetôk. A 2D modellek sorozata adja a keresett 3D kőzetvázmodellt.

\section{Közettípusok és elválasztó szerkezetek lyukgeofizika alapú felismerése}

Az egyes mintaterületeken jellemző kőzettípusok eltérő ásványos összetétele és/vagy szerkezete rendszerint kőzetfizikai különbségekben is megmutatkozik, ami lehetôvé teszi lyukgeofizikai alapú felismerésüket. A litológiai azonosítás során területenként eltérô szelvényválaszték állt rendelkezésre a makro- és mikro- fajlagos ellenállás (DLL, MLL), természetes gamma (GR), természetes potenciál (SP), caliper (CALI), neutronporozitás (CNL), sûrûség (DEN) és akusztikus terjedési idő (ATL) mérésekből.

A lyukgeofizikai információ integrálása a kôzettani azonosítás folyamatába egyszerú tanító algoritmus alkalmazásával történik. Ennek elsô lépésében a fúrómagokat petrográfiai tulajdonságaik alapján osztályokba soroljuk. A második lépésben néhány, maggal ismert mélységintervallum alapján meghatározzuk lyukgeofizikai paraméterek azon lineáris kombinációját, mely a legjobban diszkriminál a vizsgált litológiai típusok között. Ennek tesztelése és finomítása további fúrások ismert magszakaszainak bevonásával történik mindaddig, amíg a diszkriminanciafüggvény az összes ismert mélységintervallumot kôzettanilag helyesen sorolja be. Végül ezt a függvényt használjuk a maggal fel nem tárt mélységszakaszok kőzettani definiálására (FISER-NAGY et al. 2014, M. TóTH \& VARGánÉ Tóth 2020).

A kőzetblokkokat elválasztó nyírási zónák azonosítása teljesen analóg tanító algoritmussal történik azzal a különbséggel, hogy ekkor az üde és nyírt kőzetek közötti diszkriminanciafüggvényeket határozzuk meg kutanként, majd terjesztjük ki a mintaterületre (MoLNÁR et al. 2015).

\section{Vizsgált területek}

Az elmúlt évtizedekben az Alföld metamorf aljzatának fenti elvek szerinti vizsgálatát szénhidrogén-kutatási egységenként folytattuk, hiszen ez az a legkisebb lehatárolható terület, ahol minden egyes fúrómag, s minden egyes fúrás lyukgeofizikai szelvényei érdemben elemezhetők, összehasonlíthatók, s egységes rendszerben tárgyalhatók. Bár egyegy publikáció született más területekről is (pl. Sarkadkeresztúr, PÁl-Molnár et al. 2005; Battonya, BudA et al. 2012), az alábbiakban azokat a területeket részletezzük, melyeken átfogó vizsgálatok történtek (1. ábra). Ezek nyugat- 


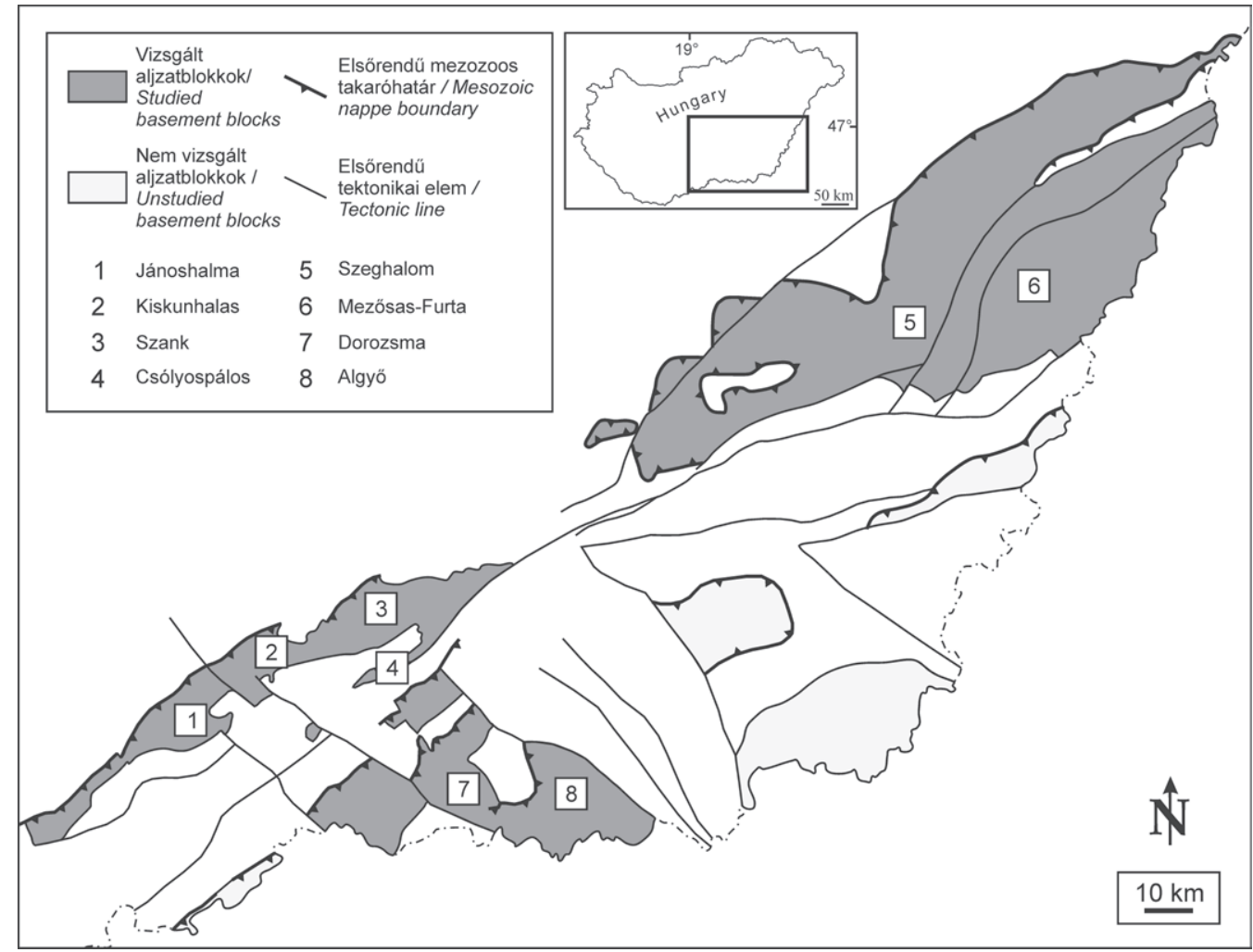

1. ábra. A részletesen elemzett aljzati mintaterületek helyzete Magyarország prekainozoos térképén (HAAS et al. 2010, 2014 alapján)

Figure 1. Position of the studied basement areas on the pre-Cenozoic map of Hungary (based on HAAS et al. 2010, 2014)

ról kelet felé a Jánoshalma, Kiskunhalas-Tázlár, Csólyospálos-Kömpöc, Szank, Szeghalom, Mezősas-Furta, majd a Dél-Alföldön Dorozsma és Algyő aljzati egységek. Az egyes mintaterületeket hasonló felépítésben, a legfontosabb eredményekre koncentrálva mutatjuk be. Helyhiány miatt a petrográfiai, kőzetkémiai, ásványkémiai, lyukgeofizikai stb. alapadatokat nem közöljük, azokat az olvasó a hivatkozott irodalmakban megtalálhatja.

\section{Eredmények}

\section{Jánoshalma}

A Jánoshalma környékén feltárt aljzatmagaslat (ZACHAR \& M. TÓTH 2004, 2009; ZACHAR et al. 2007; ZACHAR 2008) az Alföld területén a legsekélyebb helyzetú aljzati blokk, teteje kb. 400 méterrel található a jelenlegi felszín alatt. Két ütemben összesen 20 fúrás harántolta, szerkezetileg a Jh jelú fúrások mellett hozzátartoznak a Kiskunhalas-Ny jelú fúrások is. Mindezen fúrások hozzáférhető kőzetanyaga alapján a terület egységes kőzettani felépítésú, minden fúrás ortogneiszt harántolt. A gneiszes szerkezetú kôzet ásványos összetétele meglehetôsen egyveretú, egységesen $\mathrm{Qz}+\mathrm{Kfs}+\mathrm{Pl}+\mathrm{Bt} \pm \mathrm{Ms}$ alkotja (az ásványnevek rövidítését WHITNEY \& EvANS (2010) alapján az I. táblázat tartalmazza). Kiindulási, nem metamorf protolitjának intruzív magmás jellegére számos mikroszöveti bélyeg utal. Valamennyi vizsgált minta akcesszórikus ásványszemcséi (mindenekelőtt a cirkon és az apatit) saját alakúak, gyakoriak a táblás megjelenésú, gyakran mirmekites földpátszemcsék és a poligonális Kföldpáthalmazok (2. ábra, a). Fő- és nyomelem összetétele alapján a protolit szinkollíziós eredetú, peralumíniumos kemizmusú granitoid lehetett. A kőzetalkotó és járulékos alkotók mellett számos minta tartalmaz a gneisz fő alkotóival szöveti egyensúlyban nem lévő, rezorbeált amfibol és/ vagy atoll szerkezetû gránátszemcséket (2. ábra, b). Ezek

I. táblázat. A használt ásványröviditések WHITNEY \& EVANS (2010) alapján Table I. Mineral abbreviations after WHITNEY ÉS EVANS (2010)

\begin{tabular}{|l|l|l|l|l|l|}
\hline \multicolumn{1}{|c|}{ Ásvány } & Rövidítés & \multicolumn{1}{c|}{ Ásvány } & Rövidítés & \multicolumn{1}{|c|}{ Ásvány } & Rövidítés \\
\hline albit & $\mathrm{Ab}$ & hornblende & $\mathrm{Hbl}$ & muszkovit & $\mathrm{Ms}$ \\
\hline amfibol & $\mathrm{Amp}$ & ilmenit & $\mathrm{Ilm}$ & pirit & $\mathrm{Py}$ \\
\hline biotit & $\mathrm{Bt}$ & K-földpát & $\mathrm{Kfs}$ & plagioklász & $\mathrm{Pl}$ \\
\hline cordierit & $\mathrm{Crd}$ & kalcit & $\mathrm{Cal}$ & rutil & $\mathrm{Rt}$ \\
\hline dolomit & $\mathrm{Do}$ & karbonát & $\mathrm{Cb}$ & sillimanit & Sil \\
\hline epidot & $\mathrm{Ep}$ & kianit & $\mathrm{Ky}$ & spinell & Spl \\
\hline fengit & $\mathrm{Ph}$ & klinopiroxén & $\mathrm{Cpx}$ & szericit & Ser \\
\hline földpát & $\mathrm{Fsp}$ & klinozoizit & $\mathrm{Czo}$ & szerpentin & Srp \\
\hline grafit & $\mathrm{Gr}$ & klorit & $\mathrm{Chl}$ & titanit & Spn \\
\hline gránát & $\mathrm{Grt}$ & korund & $\mathrm{Crn}$ & & \\
\hline hercinit & $\mathrm{Hc}$ & kvarc & $\mathrm{Qz}$ & & \\
\hline
\end{tabular}



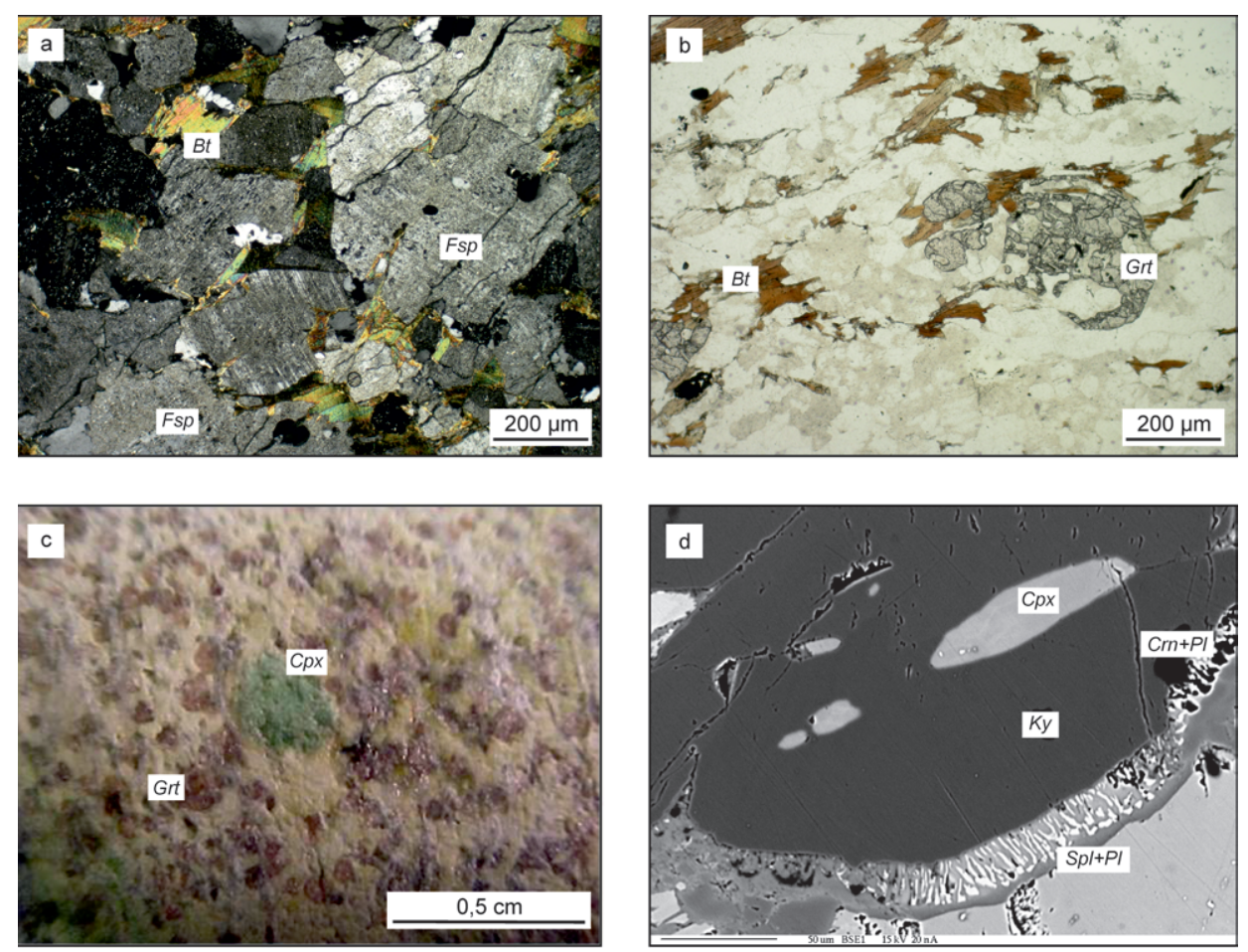

2. ábra. A Jánoshalma terület jellemző kőzettípusai. a) az ortogneisz jellemző szöveti megjelenése (+N), b) rezorbeált gránát xenokristály ortogneiszben $(1 \mathrm{~N}), \mathrm{c})$ az eklogit xenolit makroszkópos képe, d) $\mathrm{Spl}+\mathrm{P} 1 \pm$ Crn korona az eklogit kianitszemcséje körül (SEM-BSE)

Figure 2. Characteristic metamorphic lithologies of the Jánoshalma basement area. a) typical texture of the orthogneiss $(X P L), b)$ resorbed garnet xenocryst in orthogneiss $(P P L), c)$ macroscopic image of an eclogite xenolith, d) Spl+Pl \pm Crn corona around a kyanite grain of the eclogite (SEM-BSE)

megjelenésük alapján akár a metamorf fejlődés korábbi állomásainak reliktumaként megőrződött, prekinematikus szemcsék is lehetnének, de mivel összetételük idegen a kőzet kémiai rendszerétől, xenokristályoknak minôsítjük őket. A gneiszes S1 foliációt helyenként milonitos S2 foliáció írja felül, jól fejlett S/C szerkezetek, muszkovit anyagú csillámhalak megjelenése mellett.

Az amfibol és gránát xenokristályokat tartalmazó ortogneisz mellett néhány amfibolit és eklogit anyagú fúrómagot is felszínre hoztak a fúrások. A Hbl+Pl összetételú amfibolitminták intenzíven átalakultak, kapcsolatuk az ortogneisszel nem ismert. Rendkívül szerencsés ugyanakkor a JhÚ-16 fúrás által feltárt eklogitminta (2. ábra, c), hiszen esetében egyértelmúen tanulmányozható, amint az eklogit szerkezeti határ nélkül, folyamatosan megy át ortogneiszbe, a határon Grt és Cpx xenokristály-tartalmú ortogneisz megjelenésével. A xenokristályok mennyisége a mintegy 3-5 cm széles átmeneti zónában a gneisz irányában folyamatosan csökken. Mindezek alapján az eklogit az ortogneisz (és feltehetően már az eredeti granitoid) által bezárt xenolitként értelmezhetô. Az eredeti nagy nyomású kőzetben számos eredeti ásványszemcse őrződött meg, ami lehetôvé teszi metamorf fejlődésének rekonstrukcióját. A jánoshalmai eklogit az eredeti nagy nyomású (HP) ásványfázisok alapján Grt+Cpx+ $\mathrm{Ky}+\mathrm{Rt}+\mathrm{Czo}+\mathrm{Ph}$ összetételú volt. Piroxén a kőzet mátrixa mellett a gránát és kianit szemcsék zárványaiként is előfordul (2. ábra d). Intenzív retrográd átalakulás, hidratáció és karbonátosodás eredményeként a mátrix mindazonáltal túlnyomórészt $\mathrm{Amp}+\mathrm{Pl} \pm \mathrm{Cal}$ anyagú, finomszemcsés szimplektitből áll, és hasonlóan mikroszövetú Spl+ $\mathrm{Pl} \pm \mathrm{Crn}$ korona övezi a kianit porfiroblasztokat is (2. ábra, d).

A gneiszt számos fúrásban ekvigranuláris szövetû, Qz+Fp összetételú, lényegében csillámmentes, nem deformált mikrogránit telérek metszik át.

$\mathrm{Az}$ ortogneisz teljes kémiai összetétele alapján számolt DOMINo modell szerint a kiindulási granitoidból ortogneisz a metamorf fejlődés retrográd ágán keletkezett. Az M1 paragenezis kialakulásának körülményeire $T=$ $700-850{ }^{\circ} \mathrm{C}$ és $P<6,5 \mathrm{kbar}$ becsülhetô. Feltételezhetôen ezek a viszonyok a protolitot adó granitoid kőzet kristályosodási viszonyaira vonatkoznak. Az M2 ásványtársaság a hőmérséklet csökkenése mentén, $T \sim 530-580{ }^{\circ} \mathrm{C}$ körül keletkezett. Nyomásérzékeny fázis hiányában $P$ értéke nem becsülhetô.

Az amfibolit xenolitok evolúciója a kőzet bontottsága miatt nem modellezhetô. Az eklogit esetében a teljes kôzetre számított DOMINo modell alapján 680-900 ${ }^{\circ} \mathrm{C}$ és 20-27 kbar között stabil a kőzetre jellemző HP ásványtársaság $(\mathrm{Cpx}+\mathrm{Grt}+\mathrm{Ph}+\mathrm{Ky}+\mathrm{Czo}+\mathrm{Rt})$. A Fe-Mg ioncserén alapuló klinopiroxén-gránát termométerek közül PowELL (1985) módszerét használtuk, mert az egyes fázisok összetétele (pl. a gránát grosszulártartalma) ennek feltételeit teljesíti maradéktalanul. A gránát zárványaként megjelenő Cpx1 és a bezáró gránát esetén $710 \pm 10{ }^{\circ} \mathrm{C}, 725 \pm 20{ }^{\circ} \mathrm{C}$; $765 \pm 20^{\circ} \mathrm{C}$ bezáródáskori hőmérsékleteket számoltunk, míg WATERS \& MARTIN (1993) Cpx-Ph-Grt geobarométere 26,2 kbar nyomást jelez, pontosítva a fenti paragenezis modell eredményét. A mátrix klinopiroxént lényegében diopszid és hedenbergit alkotja, sugallva, hogy a kőzet szöveti alkotóiban az eredeti HP összetétele nem őrződött meg. Az alapanyagban található fengit Si-tartalma alapján (MASSONE \& SCHREYER 1987) $P=14,4 \pm 0,5$ kbar becsülhetô, ami, hasonlóan a kianit szegélyén található korund+plagioklász és spinel+plagioklász szimplektitek alapján modellezhető $P-T$ értékekhez, dekompresszió közbeni állapotokra utal.

Összefoglalóan, a Jánoshalma-dóm egy egységes ortogneisz blokk, amelynek egyik fő jellemzője a különböző kőzettípusú és metamorf fejlődéstörténetű, metabázikus kemizmusú xenolitok és xenokristályok jelenléte (3. ábra). 


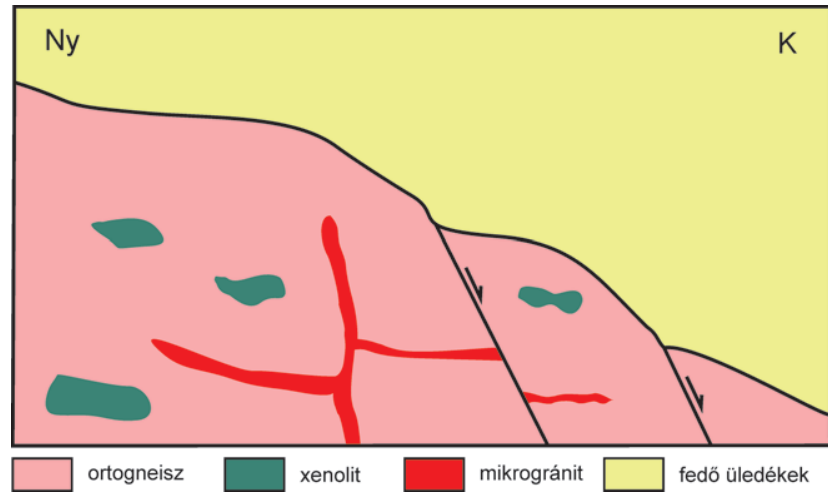

3. ábra. A Jánoshalma terület idealizált felépítése kőzettani adatok alapján Figure 3. Idealized structure of the Jánoshalma basement area based on petrological data

\section{Kiskunhalas-ÉK-Tázlár}

A Kiskunhalas-ÉK kutatási területen (FISER-NAGY \& M. TóTH 2012; FISER-NAGY et al. 2013, 2014; FISER-NAGY 2013) négy fő kőzettípust különítettünk el, melyek a kutakban tapasztalt szomszédsági és mélységviszonyok alapján az ideális kőzetoszlopban alulról felfelé a következők: ortogneisz, ortogneisz milonit, grafitos gneisz milonit és grafitos karbonátfillit. A legalsó ismert szerkezeti helyzetben lévő ortogneisztest minden szöveti tulajdonságában megegyezik a Jánoshalma területen részletezettel (4. ábra, a). Tartalmaz
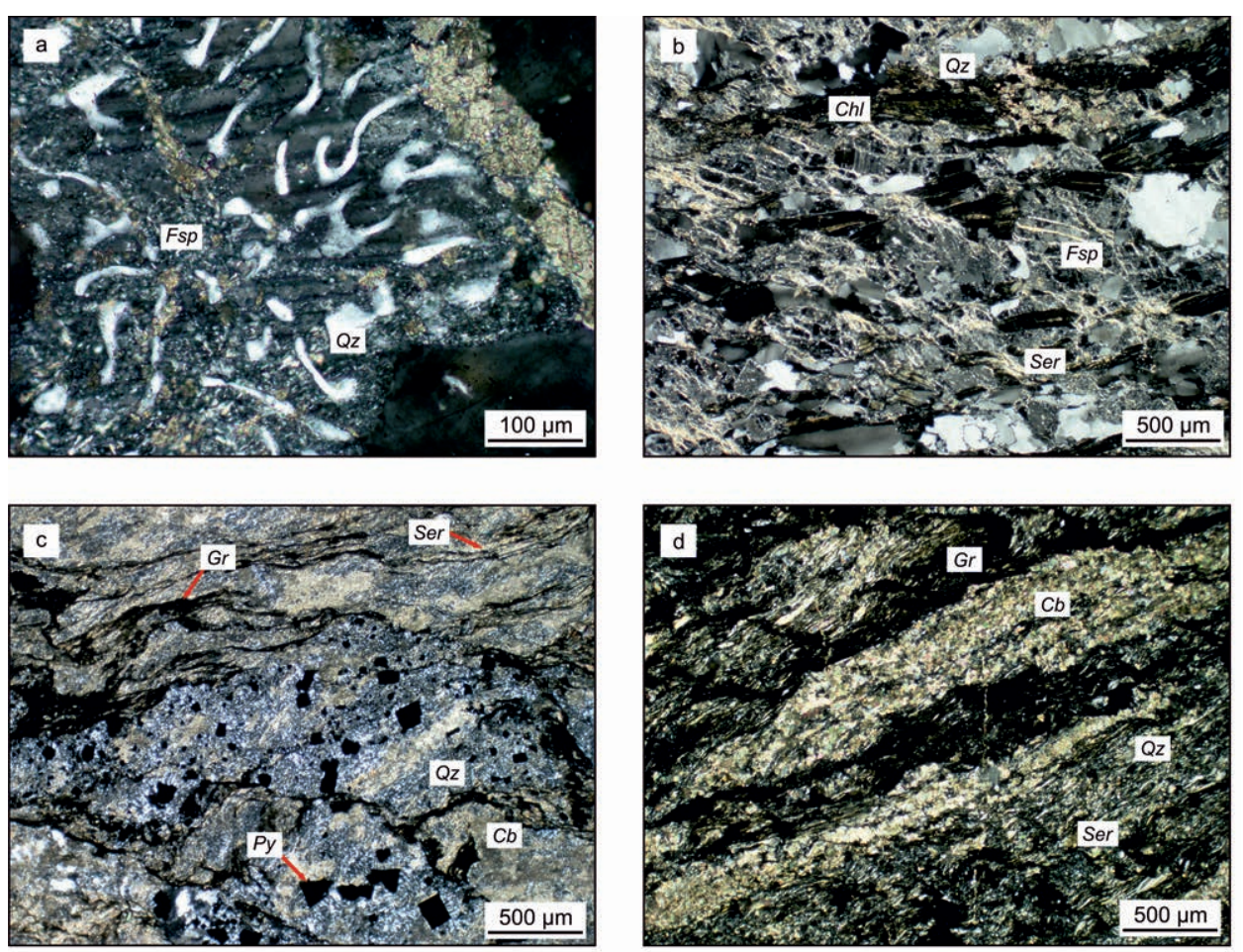

4. ábra. A Kiskunhalas-ÉK terület jellemző kőzettípusai. a) jellegzetes mirmekites földpátszemcse ortogneiszben $(+\mathrm{N})$, b) $\mathrm{S} / \mathrm{C}$ szerkezet ortogneisz milonitban $(+\mathrm{N})$, c $)$ a grafitos gneisz milonit jellemző szöveti megjelenése $(+\mathrm{N})$, d) a grafitos karbonátfillit jellemző szöveti megjelenése $(+\mathrm{N})$

Figure 4. Characteristic metamorphic lithologies of the Kiskunhalas-NE basement area. a) a typical myrmecitic feldspar grain from the orthogneiss (XPL), b) S/C structure in orthogneiss mylonite (XPL), c) typical texture of the graphite gneiss mylonite $(X P L), d)$ typical texture of the graphite carbonate phyllite (XPL) amfibol xenokristályokat, valamint több amfibolit xenolitot. Egyéb kőzetzárványt (pl. eklogitot) nem tártak fel a fúrások. A szomszédos területhez hasonlóan az ortogneisztestet csillámmentes granitoidtelérek metszik át.

Az ásványos összetétel és a jellegzetes, relikt intruzív magmás szövet jelenléte alapján ez az ortogneisz alkotja a milonitzóna alsó részén az ortogneisz milonit protolitját. A milonitra számos minta alapján jellemző szöveti bélyeg az S/C szerkezet, melyen belül az S síkokat biotit utáni kloritkötegek alkotják, míg a $\mathrm{C}$ síkokon általános a szericit megjelenése (4. ábra, $b$ ). A földpátszemcsék törésesen deformálódnak, általános a mikroboudinage szerkezetú megjelenésük. A fragmentumok közötti nyaki részen szericit, agyagásványok és kalcit megjelenése általános. A földpáttal ellentétben a kvarcszemcsék képlékenyen deformálódtak, aminek eredményeként intenzíven szabdalt szemcsehatár alakult ki. A muszkovitszemcsék csillámhal-mikroszerkezetet alkotnak. Mindezen mikroszerkezeti bélyegek alapján feltételezhetô, hogy a kiindulási ortogneisz retrográd $P-T$-út mentén, a zöldpala fácies (stabil klorit, szericit, töréses földpát és képlékeny kvarcdeformáció) viszonyai között milonitosodott. Hasonló szöveti jegyeket a Jánoshalma ortogneisz is mutat, de ott összefüggő milonitzóna léte nem igazolható.

A deformációs zónában az ortogneisz milonit mellett egyéb kőzettípus képlékenyen nyírt változata is megjelenik. Ez a kőzettípus (grafitos gneisz milonit) jellemző kőzetalkotó ásványai (grafit, pirit) alapján egyértelmúen elkülönül az ortogneisztől. Nem deformált protolitja a területen ismeretlen, és ásványos összetétele alapján elkülönül a legfelső szerkezeti helyzetben előforduló grafitos karbonátfillittől is, nagy kvarc-, földpát- és szericittartalma alapján (4. ábra, c). E nyírt kőzet esetében a Ramanspektroszkópia alapú szenes anyag termométerrel meghatározott jellemzô metamorf hőmérséklet $T=410 \pm$ $45^{\circ} \mathrm{C}$. Az R2 paraméter szórása igen nagy $(>0,1)$, a teljes zónára vonatkozó eloszlásfüggvény aszimmetrikus jellege, a kis R2 (nagy hőmérséklet) -értékek felé történő ferdeség mellett. Amennyiben az eloszlás ferdeségét a grafitszemcsék deformáltsága, esetleg nem megfelelő mértékú grafitosodás okozta volna, az a kis hőmérsékletek irányában okozna eltolódást. Ezért értelmezésünk szerint a milonitos zóna által mintázott kő- 
zetek maximális metamorf fokuk tekintetében heterogének, azaz a milonitos nyírási zónában eltérô metamorf állapotú kôzetek fordulnak elő. Bár a jellemző kőzettípusra $T \sim 410{ }^{\circ} \mathrm{C}$ adható, néhány kőzetszemcse ennél jóval nagyobb hőmérsékletet őriz. A grafitos gneisz milonit néven összefoglalt kőzettársaság így feltételezhetően viszonylag széles intervallumot képvisel a litoszférából.

A viszonylag kis kiterjedésú, legfelsố szerkezeti helyzetben lévő grafitos karbonátfillit jellegzetes, kaotikusan gyưrt sötét (szenes anyag, pirit, agyagásványok) és világos (karbonát, szericit, kevés kvarc) sávokból áll (4. ábra, d). A szenes anyagon mért hőmérsékletek szóródása jóval kisebb, mint a milonitos változat esetében. Erre a kőzettípusra $T \sim 375 \pm 15^{\circ} \mathrm{C}$ maximális metamorf hômérséklet becsülhető. Az illit kristályossági fok adatainak elemzése alapján ÁRKAI (1991) $T \sim 300^{\circ} \mathrm{C}$ csúcs metamorf hőmérsékletet becsült erre a zónára. Értelmezése szerint a grafitos karbonátfillit-zóna exotikus takarót képvisel a területen, s kontaktusa a mélyebb helyzetú, nagyobb fokú metamorf tömeggel szükségképpen tektonikus.

A kőzettest jelentős részét adó milonitos zóna petrológiailag két fő kőzettípusból épül fel. Ezek egységesen olyan szöveti bélyegeket viselnek magukon, melyek arra utalnak, hogy a milonitosodás során mikroléptékben extenziós feszültségtér alakult ki. A csillámhal, a könyvespolc (bookshelf), a mikroboudinage mikroszerkezetek egybehangzóan arra utalnak, hogy a milonitos nyírás inkább extenziós, mint kompressziós feszültségtérben zajlott (PASSCHIER \& TROUw 2005). A nyírási zóna mindkét fő litológiai egységére vonatkozóan a kvarc szutúra termométerrel meghatározott deformációs hőmérsékletük azonosan körülbelül $T \sim 450$ (440-470) ${ }^{\circ} \mathrm{C}$-nak adódott.

A rendelkezésre álló karotázs szelvény adatsorok részletes kiértékelése alapján minden egyes fúrás mentén el tudtuk különíteni az ortogneiszt a milonittól, melyben az ellenállás és a sûrúség szelvények játszottak döntő szerepet, illetve a grafitos karbonátfillitet a milonittól (FISER-NAGY et al. 2014). A két kőzettanilag elkülönülő milonitosodott kőzettípus (ortogneisz milonit, grafitos gneisz milonit) a rendelkezésre álló lyukgeofizikai adatok alapján nem elkülöníthető. Ilyen módon a kőzettani információ a vizsgált fúrások mentén kiterjeszthetô, a három litológiai egység (ortogneisz, milonitzóna, grafitos karbonátfillit) között a litológiai határok helyzete fúrásonként becsülhető, s ez alapján a teljes területre földtani szelvények szerkeszthetők. Az így kapott földtani szelvényeken a gneisz-milonit határ lapos szögú $\left(<5^{\circ}\right)$, északias dőlésú $\left(13-18^{\circ}\right)$ síknak adódik, melyet a nyírási zóna két oldalán felismert kőzettestek szignifikánsan eltérő metamorf fejlődéstörténete, valamint a deformációs zóna extenziós jellege alapján elválasztó vetôként értelmeztünk.

Így, egyetértve ÁRKAI (1991) értékelésével igazoltuk az ortogneisz és a grafitos karbonátfillit zóna közötti határ tektonikus jellegét, bár azt inkább extenziós szerkezetként értelmezzük. Szintén ezt a modellt erôsíti, hogy a nyírási zóna dőlési viszonyai nem egyeznek a kréta takarók általános, délies dőlésirányaival. Minden adatot figyelembe véve az eltérô metamorf fejlődésú ortogneisz és a legfelső grafitos kar-

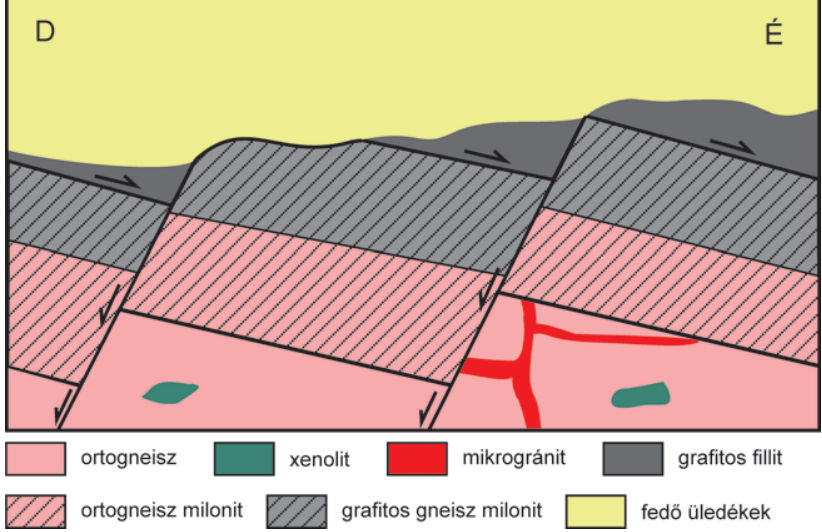

5. ábra. A Kiskunhalas-ÉK terület idealizált felépítése kőzettani és lyukgeofizikai adatok alapján. Az egyes blokkokat a fő felépítő kőzettípus jelöli

Figure 5. Idealized structure of the Jánoshalma basement area based on petrological and well-log data. Each block is named after its basic lithology, orthogneiss, mylonite in general and graphite carbonate phyllite, respectively

bonátfillit blokk kisszögű normálvető-zóna mentén, a képlékeny litoszférában (átlagos geotermikus viszonyok mellett kb. 15 km-es mélységben) került egymás mellé (5. ábra).

\section{Szank}

A szanki területen feltárt alaphegységi szerkezetről öszszefoglaló publikáció nem született, az eredményeket diplomamunkák foglalják össze (BENCSIK 2011, AGÓCs 2013, PAPP 2019). A fő kőzettípusok és azok egymáshoz viszonyított térképi elterjedése mindazonáltal ezen munkák alapján is egyértelmúen kirajzolódik.

A terület ÉNy-i részén a korábban részletesen bemutatott ortogneisz uralkodik. Szöveti jellemzői mindenben megegyeznek a Jánoshalmán és Kiskunhalason látottakkal. A kvarc-, földpátdomináns gneisz tömegben általánosan elterjedtek az amfibolit anyagú xenolitok, A folyamatos átmenetet a gneisz és annak metabázikus kôzetzárványai között több fúrás anyaga is igazolta. A szanki fúrások felszínre hoztak több eklogit anyagú xenolitot is, melyek rekonstruálható nagy nyomású ásványos összetétele lényegében azonos a jánoshalmai eklogitnál bemutatottal; $\mathrm{Grt}+\mathrm{Cpx}+\mathrm{Ky}+\mathrm{Rt}+$ Czo (6. ábra, a). A minták szövete szimplektites, a finomszemcsés Amp+Pl mátrixban nem ôrződött meg az eredeti egyensúlyi szövet. Lényeges eltérés a korábban bemutatott eklogithoz képest, hogy valamennyi szanki eklogitmintát kvarc és K-földpát anyagú granitoid mikrotelérek járják át. Ezek mentén a kôzet intenzív utólagos átalakultságot mutat, néhány cm széles zónában általános a K-metaszomatózis hatására történt másodlagos biotit- és K-földpát-keletkezés (6. ábra, b).

A kőzet alapanyagának nagymértékú átalakultsága miatt a nagy nyomású fizikai viszonyok rekonstrukciója a gráná szemcsékben megőrződött zárványok alapján lehetséges. Ezek közül megfelelő méretük miatt elsôsorban a kvarczárványok vizsgálhatók; a gyakori kianit- és rutilzárványok termometriai számításokra nem alkalmasak. Nyomásbecslésre a kvarc Raman-spektrumának változásán alapuló 

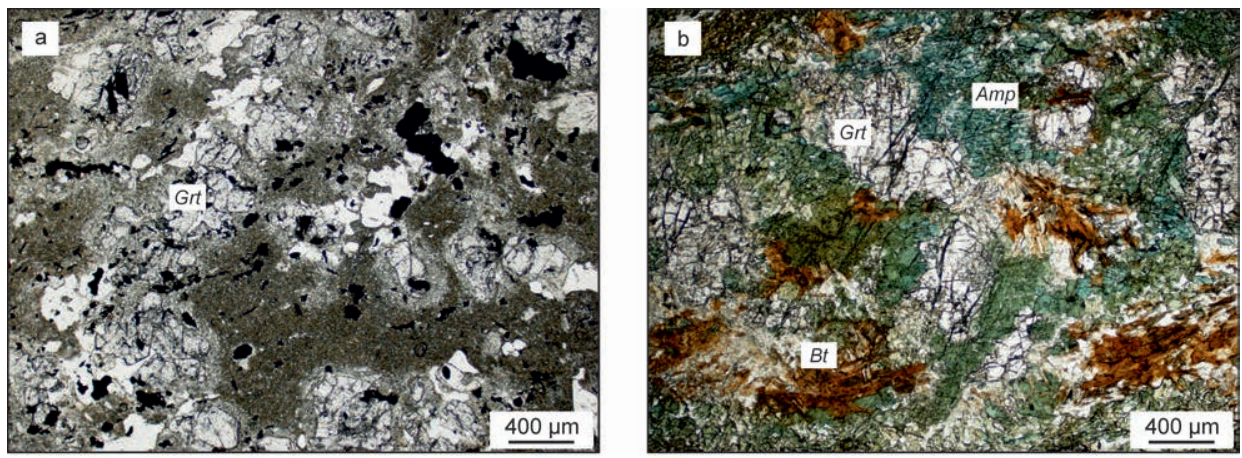

jellege egyelöre ismeretlen (7. ábra).

\section{Csólyospálos-K- Kömpöc}

A Csólyospálos környéki metamorf aljzatra (M. ТóтH et al. 2011) összességében a rossz feltártság, kevés fúrás és a nagyon rossz megtartású
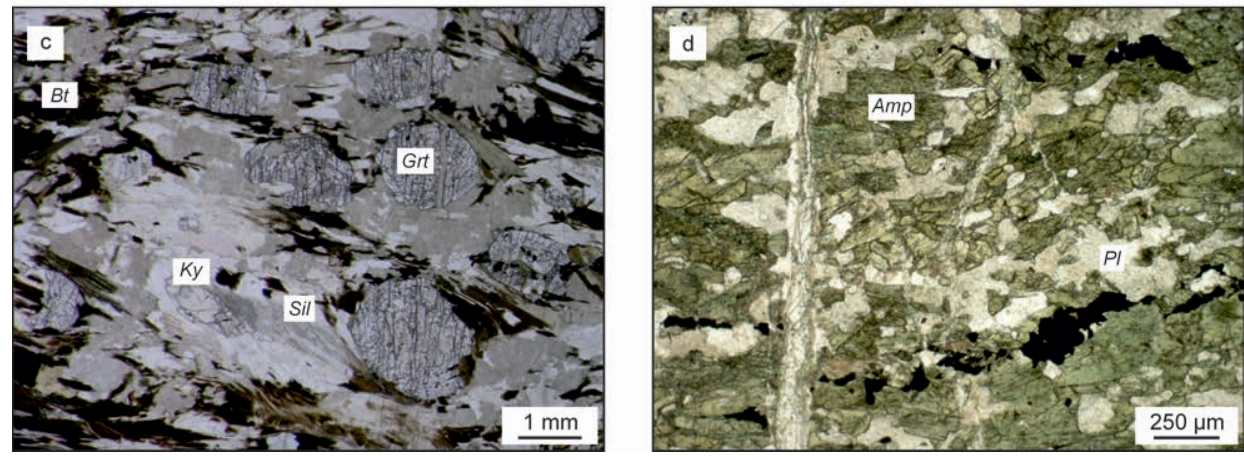
minták jellemzőek. A fő kôzettípusok szöveti megjelenésük alapján így is rekonstruálhatók, ami kiemelten fontos a regionális kép kialakítása szempontjából. A területen két fő metamorf kôzettípus tanulmányozható, a gránátos, sillimanitos paragneisz és az amfibolit/amfibolos biotitgneisz. A kőzetek minden petrográfiai jellemzôje azonosnak tekinthetô a Szank DK-i területén látottakkal. A gránátos, sillimanitos paragneisz polimetamorf, az M1 ásványtársaságban Grt1+Ky, az S2 foliáció-

6. abra. A Szank és a Csólyospálos-K terület jellemző kőzettípusai. a) az eklogit xenolit jellemzỏ szöveti képe (IN), K-metaszomatizált zóna eklogitban $(1 \mathrm{~N})$, c) a polimetamorf gránátos, sillimanitos biotitgneisz jellemző szöveti képe $(1 \mathrm{~N})$, d) az amfibolit jellemző szöveti képe (1N)

Figure 6. Characteristic metamorphic lithologies of the Szank and the Csólyospálos-E basement areas. a) typical texture of an eclogite xenolith (PPL), b) K-metasomatized zone in an eclogite xenolith (PPL), c) typical texture of the garnetiferous sillimanite biotite gneiss (PPL), d) typical texture of the amphibolite (PPL)

barométert használtuk (KoHN 2014). Ennek hőmérsékletfüggése az eklogit fáciesre jellemző $T$-intervallumban elenyésző, ezért a módszer nagyon érzékeny barométer. Hat gránátszemcse közel 50 kvarczárványa alapján konzisztens, 10,3 $\pm 0,01$ kbar bezáródáskori nyomást számoltunk, $\mathrm{T} \sim 700^{\circ} \mathrm{C}$ feltételezése mellett.

Szankon a fúrások nem tártak fel a Kiskunhalason és Tázláron jellemzố kisfokú kôzetekkel (fillit) analóg fejlődésűnek tekinthető mintákat, ahogy összefüggő milonitzónának sincs nyoma. Az ortogneisszel jellemzett ÉNy-i blokktól DK-felé, gránátos, sillimanitos paragneisz a jellemzó litológia. Határa az ortogneisz-zónával nem ismert. Szöveti megjelenése alapján egyértelmúen polimetamorf képződmény, az M1 metamorf eseményt Grt1+Ky index ásványok és rutil, míg az M2 állapotot Grt2+Sill jellemzi. Mindezek alapján a kôzet normál Barrow-zonáció mentén metamorfizálódott. BENCSIK (2011) az M2 eseményre $T<700{ }^{\circ} \mathrm{C}$ és $P<8,5$ kbar fizikai körülményeket modellezett.

A szanki terület DK-i részén amfibolit és amfibolos biotitgneisz a jellemző kőzettípusok, kevés biotitgneisz és különböző mészszilikát kôzetek (AGócs 2013) előfordulása mellett. Ezek Domino modelljeinek egyesítése alapján a zónára 550-600 ${ }^{\circ} \mathrm{C}$ és 3,5-6,5 kbar metamorf $P-T$-ablak adható (BENCSIK 2011). Bár a gránátos, sillimanitos paragneisz és az amfibolitdomináns blokkokra modellezett $P-T$-ablakoknak van közös része, az elóbbi nagyobb metamorf fokú képződményként értékelhetô, ami miatt a két képződmény határa feltételezhetốen posztmetamorf. Ezzel együtt a határ hoz kapcsolódó M2 paragenezisben Grt2+Sil+Ilm $\pm \mathrm{Gr}$ összetétellel (6. ábra, c). A gránátban azonosítható S1 prekinematikus zárványsorokban általános a rutil megjelenése. Mindezek alapján a kőzet fejlődése normál Barrow-féle $P$ $T$-úttal jellemezhetô. A számottevô késői átalakulás miatt termobarometriai számításra a kôzet leginkább ellenálló ásványa, a grafit alkalmas. Raman-spektrum alapú grafit termometria alapján az M2 eseményre számítható hőmérséklet

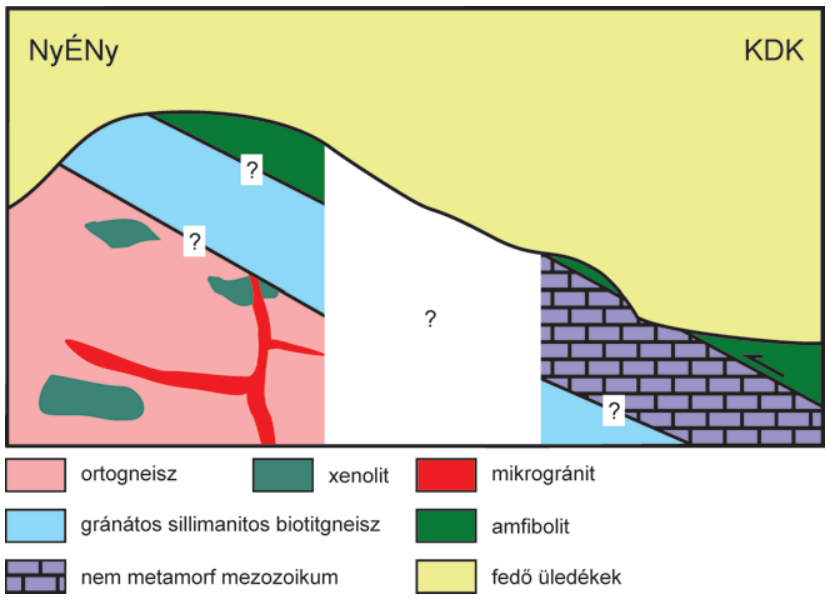

7. ábra. A Szank és a Csólyospálos-K terület idealizált felépítése kőzettani adatok alapján. Az egyes blokkokat a fö felépitő kőzettípus jelöli

Figure 7. Idealized structure of the Szank and the Csólyospálos-E basement areas based on petrological data. Each block is named after its basic lithology, orthogneiss, garnetiferous sillimanite biotite gneiss, and amphibolite 
$T_{\max } \sim 630{ }^{\circ} \mathrm{C}$, ami beleesik a sillimanit stabilitási tartományába. Ez alapján a gránátos, sillimanitos paragneisz bizonyosan nem azonosítható a Kiskunhalas-ÉK területen jellemző, hasonlóan grafittartalmú, kisfokú metamorf képződményekkel, melyeknek viszont a csólyospálosi területen nincs nyoma.

Néhány magszakasz képviseli az amfibolit (Csó-K-3, Köm-4) és az amfibolos biotitgneisz (Csó-K-4, Köm-5) kőzettípust (6. ábra, $d$ ). Ezen metabázikus kőzetek ásványos összetétele azonos a Szankon látottakkal, ugyanakkor intenzíven átalakultak, rajtuk nem lehetséges termobarometriai számítást végezni.

Az aljzati minták többsége intenzíven deformált; a gránátos, sillimanitos paragneiszben korai milonitos deformációt felülíró töréses deformáció a jellemző. A gneisz kataklázit és vetőbreccsa anyagú minták klasztjainak anyaga paragneisz milonit azt sugallva, hogy a töréses alakváltozás ugyanazon nyírási zónák mentén képlékeny deformációt írt felül. A kőzetoszlopban gyakori a perm homokkő és a különbözô mezozoos (triász, jura, BÉRCzINÉ MAKK 1998; ÁRKAI et al. 2000) karbonátos kőzetek megjelenése, gyakran az amfibolit, amfibolos bitotigneisz alatt. A Köm-5 fúrás esetén triász és jura képződmények alkotják az amfibolos biotitgneisz feküjét, melyek alatt a fúrás nem ért el más metamorf képződményeket. Más esetekben (Csó-K-3) dolomitbreccsa választja el az amfibolitot a gránátos, sillimanitos paragneisz szakasztól. Mindezek alapján ismeretlen szerkezeti helyzetú egységként írhatjuk le az amfibolittal, amfibolos biotitgneisszel jellemezhető blokkot, mely bizonyosan posztmetamorf mozgások eredményeként került jelenlegi helyére. A gránátos, sillimanitos paragneiszből álló metamorf aljzat és a dominánsan amfibolit anyagú ,,pikkely”(?) között helyenként kb. 500 m mélységeltérés is előfordul.

Bár a rossz feltártság és a minták rossz állapota miatt a szerkezet a kőzettani információ alapján részletesebben nem rekonstruálható, a Csólyospálos-Kömpöc terület felépítése sok szempontból azonosítható a szanki terület felépítésével. Mindkét területen gránátos, sillimanitos paragneisz és magasabb szerkezeti helyzetben amfibolit a jellemző kőzettípusok. Míg Csólyospáloson igazolt a két képződmény közötti szerkezeti (mezozoos, posztmezozoos?) szerkezeti határ léte, Szankon ez a határ, a két képződmény eltérő metamorf fejlődése miatt, csak feltételezhető (7. ábra).

\section{Szeghalom}

Valamennyi aljzati mintaterület közül a legtöbb vizsgálat a Szeghalom-hát területén történt (M. TóTH et al. 2000, 2003, 2008; SchuberT et al. 2007; BALOGH et al. 2009; MolnáR et al. 2015; M. Tóth \& SCHUBERT 2018). Ennek fő oka az, hogy itt mélyült a legtöbb aljzatot elérő fúrás, melyek közül négy több tíz méteren keresztül maggal tárta fel az aljzati képződményeket.

A területen három fô litológiai típus azonosítható, melyek relatív helyzete több fúrás alapján meghatározható. Legalsó szerkezeti helyzetben a korábbiakkal mind ásványos összetételében, mind mikroszöveti megjelenésében rendkívül hasonló ortogneisz található. Hasonlóan a fent bemutatott területek ortogneiszeihez, itt is jellemző a különböző xenokristályok (amfibol, gránát) és xenolitok előfordulása (8. ábra, a). Ez utóbbiak legnagyobb része az általánosan megjelenő amfibolit és gránátos amfibolit, de néhány eklogitminta is előfordul. Egyetlen fúrásban (Szh-15) mindezek mellett felzikus granulit anyagú xenolit is megjelent (8. ábra, b). Az ortogneisz zöldpala fáciesú milonitos átalakulása szintén jellemzô, az egykori képlékeny nyírási zóna menti kőzetátalakulás több fúrás anyaga esetében követhető. A milonit mikroszöveti jellemzői azonosak a korábban bemutatottakkal.

A végig maggal mélyített fúrások tanúsága szerint széles, kataklázos nyírási zóna mentén az ortogneisz blokk fölött a területen egységesen gránátos, sillimanitos paragneisz következik, mely szöveti jellemzői alapján hasonló a Szank és Csólyospálos területen bemutatott, analóg kőzettípushoz. Itt is jellemző a polimetamorf jelleg M1 Grt1+Ky és M2 Grt2+Sil index ásványokkal (8. ábra, c). Az index ásványok sorozata, valamint az M1 gránátok rutilzárványai Szeghalmon is normál, Barrow-típusú metamorf evolúcióra utalnak. Legfelsô szerkezeti helyzetben (szintén kataklázittal jellemzett nyírási zóna mentén) amfibolit és amfibolos biotitgneisz következik. E két kôzettípus (hasonlóan a Szankon és Csólyospáloson bemutatott esethez) felváltva jellemzi a legfelsô szerkezeti zónát. Az amfibolitok a kőzetalkotó Hbl+Pl mellett rendszerint tartalmaznak epidotot, ilmenitet és esetenként apró gránátszemcséket is. Ellentétben a Szankon megfigyelttel, Szeghalmon mészszilikát kőzeteket nem találunk a legfelsố szerkezeti blokkban.

A nagyszámú fúrás és az ezekben rendelkezésre álló lyukgeofizikai szelvények kiértékelése alapján a három kőzetblokkot elválasztó kataklázitzónák térbeli helyzetét elemezte MolnÁr et al. (2015). Eredményeik alapján az egyes fúrásokban azonosítható nyírási zónák DK-i irányban kb. $11^{\circ}$-kal dőlő síkokat definiálnak, melyeket erre közel merőleges irányú normál vetők szabdalnak blokkokra. A lapos szögú szerkezeti elemeket, valamit az azokat elvetô normál vetőket szeizmikus szelvények értelmezésével M. TóTH et al. (2008) is kimutatták.

A három szerkezeti egység kőzetein végzett termobarometriai vizsgálatok eredménye az alábbiakban foglalható össze. Az ortogneisz átalakulása $9 \mathrm{db}$, muszkovittartalmú gneiszminta DoMino modellje alapján $500-600{ }^{\circ} \mathrm{C},<8 \mathrm{kbar}$. Ezt a hőmérsékletet alátámasztja az irányított szemcséken mért Ti-a-biotitban (HENRY et al. 2005) termometriai számolás eredménye is, mely nagyszámú szemcse alapján $T=550-620^{\circ} \mathrm{C}$. Ugyanezen biotitszemcsék magas Ti-tartalmú magjai esetében a keletkezési hőmérséklet $T>700{ }^{\circ} \mathrm{C}$ ra becsülhető, igazolva azok magmás eredetét. Az alkáli és plagioklász földpátok közös szemcsehatárán történt rekrisztallizáció eredményeként a metamorfózis viszonyai között ezek a fázisok is egyensúlyba jutottak. A szemcseperemi összetételek alapján történt termometriai becslés $T \sim 600^{\circ} \mathrm{C}$-ot eredményez $P<5$ kbar feltételezése mellett.

A szeghalmi ortogneisz jó feltártsági viszonyai miatt számos xenokristály és xenolit elemzésével azok metamorf 

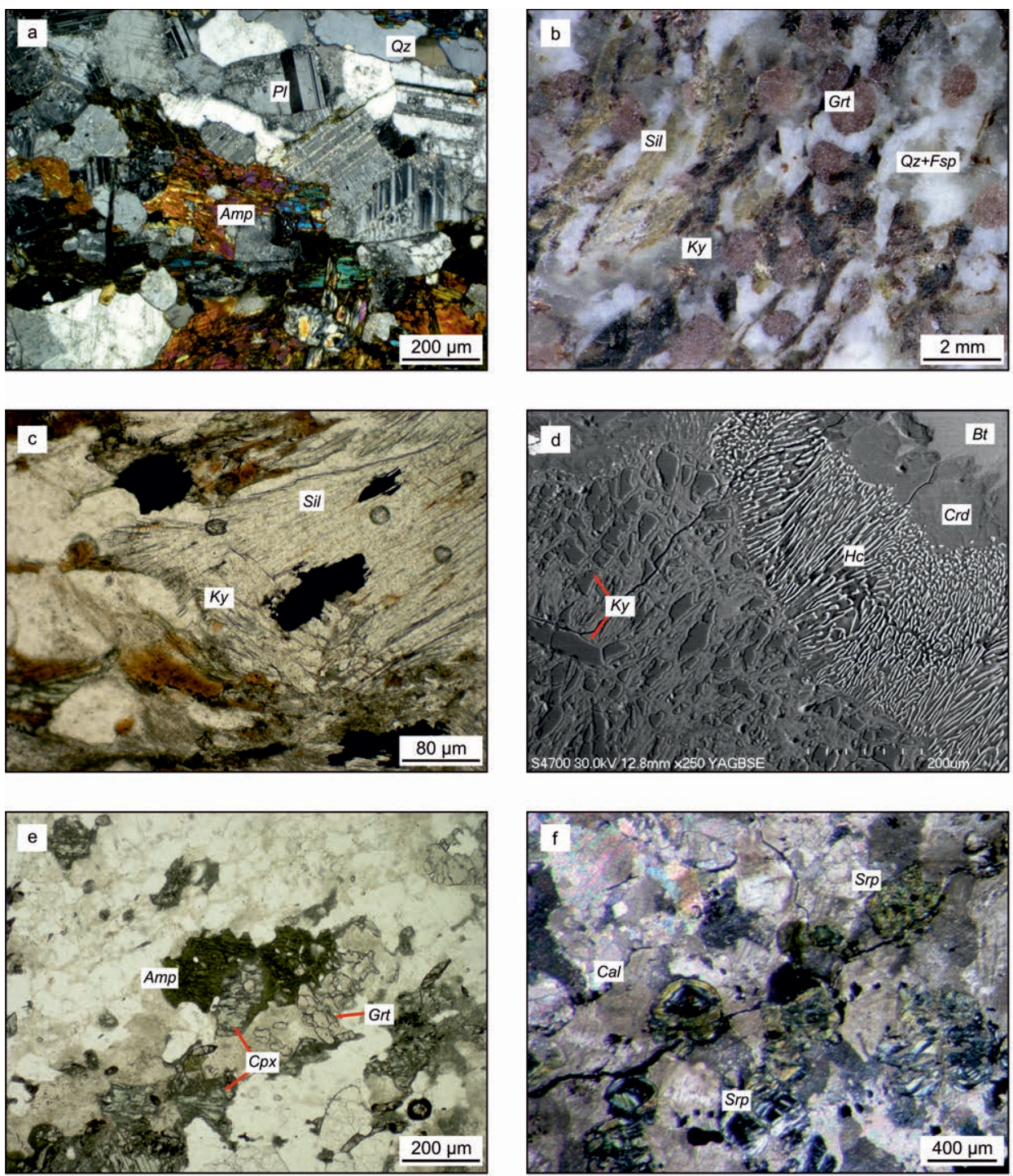

8. ábra. A Szeghalom és a Mezősas-Furta terület jellemző kőzettípusai. a) amfibol xenokristályok ortogneiszben $(+\mathrm{N})$, b) a felzikus granulit xenolit makroszkópos képe, c) a gránátos, sillimanitos biotitgneisz jellemző szöveti képe (1N), d) Crd+Spl tartalmú korona a granulit kianit- és biotitszemcséje határán (SEM-BSE), e) Amp, Cpx és Grt xenokristályok ortogneiszben (1N), d) olivin utáni szerpentin pszeudomorfózák forsterites márvány xenolitban (1N)

Figure 8. Characteristic metamorphic lithologies of the Szeghalom and the Mezösas-Furta basement areas. a) amphibole xenocryst in orthogneiss (XPL), b) macroscopic image of the felsic granulite xenolith, $c$ ) typical texture of the garnetiferous sillimanite biotite gneiss (PPL), d) Crd+Spl corona at the contact of kyanite and biotite grains of the granulite xenolith (SEMBSE), e) Amp, Cpx and Grt xenocrysts in orthogneiss (PPL), f) serpentine pseudomorphs mimicking previous olivine grains in a forsterite marble xenolith (PPL)

fejlődése is részletesen tanulmányozható. Számos mintában vizsgálva a gránát xenokristályok kémiai összetétele széles intervallumon belül változik, azt sugallva, hogy azok nagyon különböző metamorfitokat reprezentálnak. Akár ugyanazon mintán belül is találunk eltérő, metabázikus és metapelites összetételú kôzetre utaló gránátszemcséket is. Ezen gránátok termobarometriai számításra nem alkalmasak, hiszen - feltételezhetôen - idegen szemcseként kerültek az ortogneisz anyagába, s annak ásványaival a későbbi metamorf fejlődés során sem jutottak egyensúlyba. A vizsgált amfibol xenokristályok pereme ugyanakkor átkristályosodott a metamorf viszonyok között, s mindegyikük hasonló zonációt mutat. Ez alapján GERYA et al. (1997) termobaro- méterét használva $T \sim 660-680{ }^{\circ} \mathrm{C} \rightarrow 580-620{ }^{\circ} \mathrm{C}$ hőmérséklet és $P \sim 3,0-4,5$ kbar $\rightarrow$ 2,0-3,5 kbar nyomásváltozási trend általánosítható. Azaz a nagyobb $P-T$-n keletkezett amfibol xenokristályok peremei a befoglaló ortogneiszhez hasonló fizikai körülmények között alakultak át és jutottak egyensúlyba.

A részletesen vizsgált xenolitok korai metamorf fejlődése, különösen a nyomás vonatkozásában, számottevően eltér egymásétól. A vizsgált gránátos amfibolitokban a gránátamfibol-plagioklász paragenezis $\sim 620{ }^{\circ} \mathrm{C}$ keletkezési hőmérsékletet (GRAHAM \& POWELL 1984) és 7,5-8,2 kbar nyomást sugall (KOHN \& SPEAR 1991). A vizsgált eklogit xenolitok esetében átlagosan $T\left(P_{\max }\right) \sim 800{ }^{\circ} \mathrm{C}$ és $P_{\max } \sim 15 \mathrm{kbar}$ 
maximális metamorf állapot adható. Mindezen kőzetzárványok esetében kimutatható a késői metamorf felülbélyegzés $T \sim 600{ }^{\circ} \mathrm{C}$ és $P<3,0$ kbar, azaz az ortogneisz átkristályosodásával megegyező körülmények között.

$\mathrm{Az}$ egyetlen granulit xenolitot a $\mathrm{Qz}+\mathrm{Pl}+\mathrm{Kfs}+\mathrm{Bt}+$ $\mathrm{Grt}+\mathrm{Ky}+\mathrm{Rt} \mathrm{M} 2$ paragenezis jellemzi. A részben hasonló (+Ph), korábbi állapotot ôrző M1 metamorf ásványtársaság a gránátszemcsék zárványaiként őrződött meg. Az M3 esemény során nagy méretú, irányított sillimanitkötegek és biotitlécek keletkeztek; a kianit körül kordierit ( \pm spinell) tartalmú komplex korona mikroszövetek fejlődtek ki (8. ábra, d). A granulit xenolit és a befoglaló ortogneisz kontaktusa jól tanulmányozható a fúrómagon, ami bizonyosan nem tektonikus, mivel az M3 biotit és az ortogneisz metamorf eredetűnek minősíthető biotitszemcséinek irányítottsága megegyezik. A granulit maximális fokú metamorf átalakulása fengitzárvány és gránátmag összetételének adatai alapján $T \sim 820-850{ }^{\circ} \mathrm{C}$ (GREEN \& Hellman 1982), $P \sim 13$ kbar mellett (Si-a-fengitben barométer, MASSONE \& SCHREYER 1987). Számottevő húlés és dekompresszió után a kianitot körülvevő korona minden formájában kis nyomáson történt felfütés eredményeként jött létre $T=650 \pm 10{ }^{\circ} \mathrm{C}$ és $P=3,1 \pm 0,1$ kbar viszonyok között. Ezt a hőmérséklet-növekedést az eredeti granitoidolvadéknak a granulit kőzetzárványon okozott izobár kontakt hatásaként értelmezzük.

$\mathrm{Az}$ ortogneisz milonitos nyírása kvarcszutúra-elemzés alapján kb. $T \sim 430{ }^{\circ} \mathrm{C}$-on történt. Ezt az értéket alátámasztja a kőzet szöveti megjelenése is, hiszen a kvarc képlékeny deformációja $T>270{ }^{\circ} \mathrm{C}$, míg a földpát egyidejű töréses viselkedése $T<450{ }^{\circ} \mathrm{C}$ hőmérsékletre utal (VoLL 1980, WHITE et al. 1980). Az azonos megjelenésú ortogneisz képlékeny nyírásának becsült hőmérséklete megegyezik a Kiskunhalason meghatározott milonitosodási hőmérséklettel, ami összevethetô litoszféra mélységben lezajlott hasonló geodinamikai folyamat eredményére utal. A szeghalmi ortogneiszből

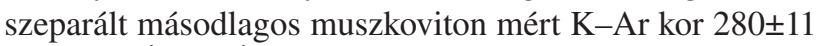
M év (Sz-É-11). Így az ortogneisznek a metamorfózis retrográd ágán, zöldpala fáciesben történt milonitosodása feltehetően az orogén kora perm exhumációjához köthető.

A szeghalmi gránátos, sillimanitos paragneisz esetén lehetôség volt a teljes metamorf $P-T$-út rekonstrukciójára (M. Tóтн 2008). Az M1 eseményre a gránátmagok és biotitzárványok 730-750 ${ }^{\circ} \mathrm{C}$ keletkezési hőmérsékletet sugallnak (BHATTACHARYA et al. 1992), míg a GASP barométer (kianit feltételezése mellett) alapján $P=7,5-7,8$ kbar számolható. Ugyanezen módszerek a mátrix paragenezis, a gránát peremi összetétele és sillimanit feltételezése alapján az M2 eseményre $T \sim 630-650{ }^{\circ} \mathrm{C}$ és $P \sim 4-5$ kbar értékeket becsülnek. A kőzet mátrixában és biotit zárványaként megjelenő monacit U-Pb geokémiai kora 361,4×47,6 M év, míg izotóp kora 330 7,1 M év. A kőzet cirkonszemcséin mért hasadványnyom kor 166,5 $\pm 14,7$ (BALOGH et al. 2009). Azaz a variszkuszi orogenezis során keletkezett metamorf tömeg feltehetően a Pennini-óceán kinyílásával egyidejû litoszféra-vékonyodás eredményeként került a litoszféra sekély mélységébe.

A legfelső szerkezeti helyzetben lévő amfibolit, amfibolos gneisz egység monometamorf képződmény. Egyensúlyi amfibol-plagioklász ásványpárok alapján a maximális hômérsékleten jellemző metamorf állapot körülményeire különböző módszerek hasonló eredményeket adnak. Így $T=550-570{ }^{\circ} \mathrm{C}$ (Holland \& Blundy 1994), $T \sim 560{ }^{\circ} \mathrm{C}$ és $P=3-4$ kbar (Gerya et al. 1997), valamint $\mathrm{T} \sim 530{ }^{\circ} \mathrm{C}$ $P \sim 4$ kbar (PlYUSNINA 1982). A kőzet amfibolszeparátumán mért K-Ar adatok irreálisan fiatal, középsô triász kort ad-

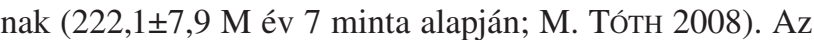
amfibol és plagioklász Ar-Ar korspektrumának legidősebb plató korai mindazonáltal igazolják a variszkuszi metamorfózist $(293,7 \pm 13,8$, illetve 333,3 $\pm 14,4$ M év; BALOGH et al. 2009).

Mindezek alapján a teljes Szeghalom területen nyomozható, lapos szögú nyírási zónák által elválasztott három egység metamorf fejlődése számottevően eltér egymásétól ( 9 . ábra). Így jelenlegi helyzetükbe posztmetamorf szerkezeti mozgások eredményeként kerültek. Mivel az elválasztó nyí-

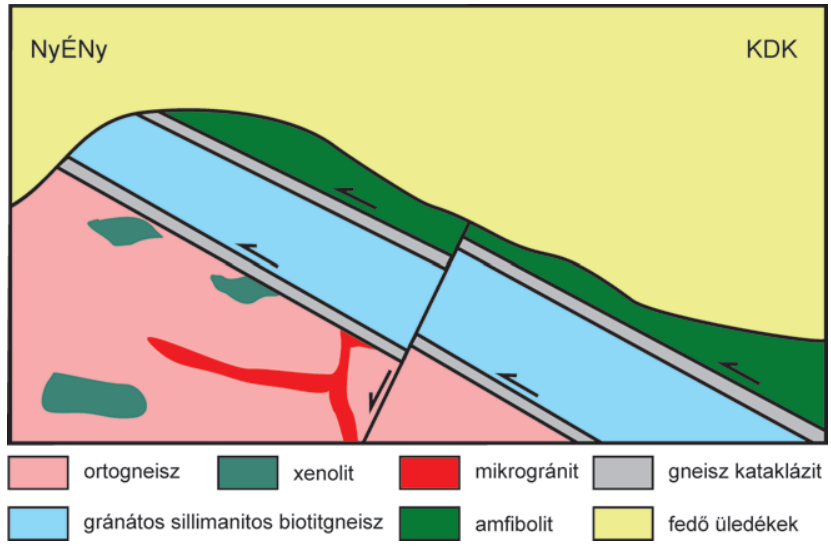

9. ábra. A Szeghalom és a Mezősas-Furta terület idealizált felépítése kőzettani és lyukgeofizikai adatok alapján. Az egyes blokkokat a fő felépítő kőzettípus jelöli

Figure 9. Idealized structure of the Szeghalom and the Mezösas-Furta basement areas based on petrological and well-log data. Each block is named after its basic lithology, orthogneiss, garnetiferous sillimanite biotite gneiss, and amphibolite

rási zónák jellemző tektonit kőzettípusa a kataklázit, a nyírás feltehetően a litoszféra felső, töréses zónájában zajlott a metamorf tömeg középsố jura kiemelkedését követôen. Ez alapján feltételezhető, hogy a kristályos tömegen belüli DK-i dőlésú nyírási síkok az alpi takarórendszer valamely szerkezeti határait alkotják.

\section{Mezósas-Furta}

A két kutatási terület ugyanazon aljzatkiemelkedésen található, Mezősas a központi és déli, míg Furta az észak felé lejtő területen. Kőzettani felépítésük azonos a nyugati szomszéd, Szeghalom területen bemutatottal (M. TóTH \& ZACHAR 2006, BALOGH et al. 2009). Az északi, furtai terület kizárólagos kőzettípusa az ortogneisz, míg dél felé a magasabb szerkezeti helyzetú egységek is megjelennek. A furtai fúrások által feltárt ortogneisz különlegessége, hogy itt a korábbiaknál is változatosabb xenokristály $(8$ a ábra, e) és xenolittartalom jellemző (minden egyéb petrográfiai tulaj- 
donság azonossága mellett). A korábban látottak mellett Furtán előfordulnak ultrabázikus és mészszilikát összetételû kôzetzárványok is. Ez utóbbiakban az egykori olivinkristályok lizardit anyagú pszeudomorfózái (8. ábra, f) utalnak a korábbi forszterites márvány jelenlétére (M. TóTH \& ScHUBERT 2018). Metakarbonát rendszerben olivin keletkezése rendszerint nagy hômérséklethez és kis $\mathrm{CO}_{2}$ fugacitáshoz (nyílt rendszerhez), s így kontakt metamorf viszonyokhoz kapcsolódik. Így a forszterites márványxenolit protolitja, hasonlóan a többi kôzetzárványhoz, az eredeti granitoid magmába került idegen kőzettest lehetett, s kezdetben annak hőhatására kontakt metamorfózist szenvedett, majd regionális metamorf körülmények között tovább fejlődött a gránit ortogneisszé alakulása folyamán.

A főleg a mezősasi fúrások által feltárt felső szerkezeti egységek, a gránátos, sillimanitos paragneisszel és az amfibolittal jellemzett blokkok minden tulajdonsága megegyezik a Szeghalom területen látottakkal.

\section{Dorozsma}

A Dorozsma kutatási területen mélyült fúrások petrográfiai feldolgozásának eredményeként (LELKES-FELVÁRI et al. 2005, M. TóTH 2008, PAPP et al. 2017, M. TóTH \& VARGÁNÉ TóTH 2020) alapvetôen három fő kôzettípus (és ezek számos altípusa) azonosítható. Ezek térbeli kapcsolatrendszerét számos fúrás igazolja, de legjobban a végig maggal fúrt Do-54 tárta fel. Legalsó szerkezeti helyzetben tömeges amfibolit és kisebb jelentőséggel amfibolos biotitgneisz, kloritos biotitgneisz a jellemzô. Az amfibolit összetétele Amp+ $\mathrm{Pl}+\mathrm{Spn} \pm \mathrm{Epi} \pm \mathrm{Chl} \pm \mathrm{Gr} \pm \mathrm{Bt}$. A biotit rendszerint $\mathrm{Mg}$ klorittal közberétegzett formában jelenik meg (10. áb$r a, a)$. A kloritos biotitgneisz esetenként tartalmaz gránátot, de más index ásvány (pl. kianit) nem fordul elô benne. Különös szöveti jellemzője a dinamikusan rekrisztallizálódott földpátszemcsék statikus rekrisztallizációja, aminek eredményeként nem deformált, poligonális földpátkorona övezi a nagy méretú földpátklasztokat.

$\mathrm{Az}$ amfibolit által meghatározott zóna fölött dolomitmárvány a jellemző kőzettípus, melyet dolomit-, kevés kvarc- és muszkovit - szemcsék mellett klorit és talk mint maximális fokú metamorf ásványok alkotnak. Bár a dolomitmárványnak különböző mértékben deformált típusai fordulnak elő a területen, ezt a legfeljebb néhányszor tíz méter széles zónát elsősorban dolomitmárvány anyagú kataklázit alkotja (10. ábra, b).

Legfelső szerkezeti helyzetben elsősorban gránátos, kianitos biotitgneisz található. A kőzet polimetamorf megjelenést mutat, a gránát zárványaiként megjelenő M1 Qz+Pl+ $\mathrm{Kfs}+\mathrm{Bt}+\mathrm{Ms}+\mathrm{Rt}$, valamint a kőzet mátrixát alkotó M2 Qz+ $\mathrm{Pl}+\mathrm{Kfs}+\mathrm{Bt}+\mathrm{Grt}+\mathrm{Ky}+\mathrm{Ilm}$ ásványtársasággal (10. ábra, c). $\mathrm{Az}$ amfibolit zóna kloritos biotitgneiszeinél látotthoz hasonlóan ebben a zónában is jellemző a földpát dinamikus, majd statikus rekrisztallizációja (10. ábra, d), azonban a koronát alkotó földpátszemcsék mérete itt számottevően nagyobb, mint az az alsó zónában jellemző (150-150 szemcse elemzése alapján átlagosan 148, ill. 45 mikron).

Ezt az általános szekvenciát valamennyi aljzatot elért fúrás lyukgeofizikai adatainak litológiai célú értelmezése is alátámasztotta, ami egyúttal lehetőséget adott a kőzettani információ térbeli kiterjesztésére. A három fô kőzetblokk térbeli helyzetének geofizikai alapú meghatározása igazolta, hogy a nyírt dolomitmárvány-zóna átlagosan 36\%/18 helyzetû síkot, illetve normálvetôkkel szabdalt síkokat definiál az amfibolit és a gránátos, kianitos biotitgneisz-zóna között (M. TóTH \& VARGÁNÉ TóTH 2020).

A három kőzettanilag eltérő felépítésú blokk metamorf
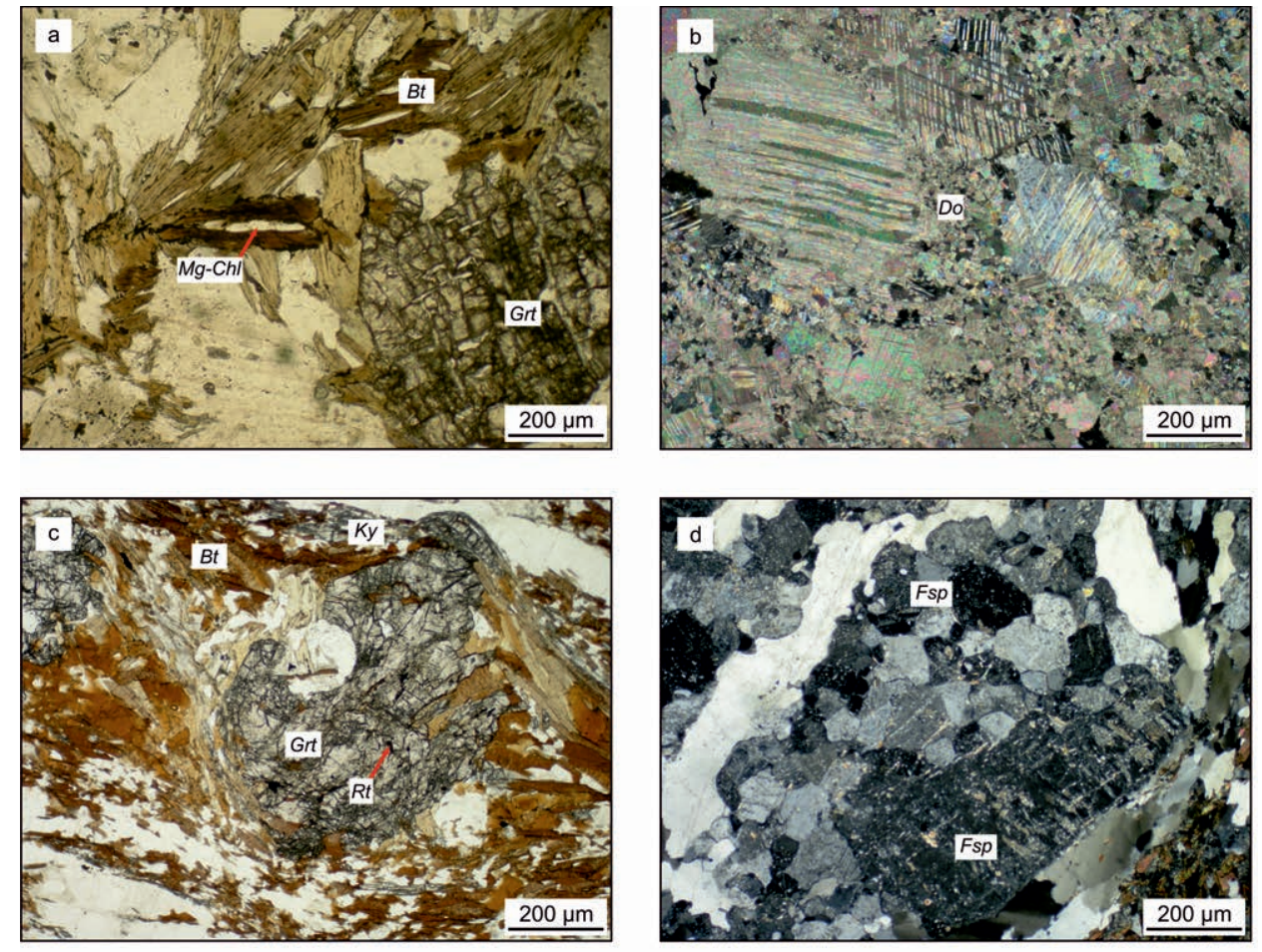

10. ábra. A Dorozsma terület jellemző kőzettípusai. a) Mg-klorittal közberétegzett biotit a kloritos biotitgneiszben (1N), b) a dolomitmárvány kataklázit jellemző szöveti képe $(+N)$, c) a polimetamorf gránátos, kianitos biotitgneisz jellemző szöveti képe $(1 \mathrm{~N})$, d) statikusan rekrisztallizált, burkolt földpát porfiroklaszt gránátos, kianitos biotitgneiszben $(+\mathrm{N})$

Figure 10. Characteristic metamorphic lithologies of the Dorozsma basement area. a) biotite interlayered with Mg-chlorite in chlorite biotite gneiss (PPL), b) typical texture of the dolomite marble cataclasite (XPL), c) typical texture of the polymetamorphic garnetiferous kyanite biotite gneiss (PPL), d) recrystallized mantled feldspar porphyroblast in garnetiferous kyanite biotite gneiss (XPL) 
fejlődéstörténete markánsan eltér egymásétól. A legfelső zóna metamorf útja DoMINo modellezés alapján $P_{\max }>6,5$ kbar, $T\left(P_{\max }\right)<650{ }^{\circ} \mathrm{C}$, majd $T_{\max }>600{ }^{\circ} \mathrm{C}, P\left(T_{\max }\right)<6,5$ kbar intervallumokkal adott metamorf út mentén zajlott. Ezt a becslést a Ti-a-biotitban termometria (HENRY et al. 2005) eredményei is alátámasztják; a gránát zárványaként megjelenô biotit keletkezésére $\sim 650{ }^{\circ} \mathrm{C}$, míg a mátrix biotitéra $\sim 730{ }^{\circ} \mathrm{C}$ számítható. A kőzet a húlő fázisban (a retrográd út mentén), de még a földpát képlékeny deformációjának hőmérsékletén $\left(>400{ }^{\circ} \mathrm{C}\right)$ milonitosodott. Ennek a milonitos nyírásnak az eredményei a deformált, majd statikusan rekrisztallizált földpátszemcsék, melyek átkristályosodása szemcseméret termométer alapján a kb. $580^{\circ} \mathrm{C}$ hőmérsékleten zajlott. Az amfibolittal jellemzett alsó zóna kloritos biotitgneisz tagjai bizonyosan kisebb metamorf fokot értek el, hiszen sem az adott kémiai rendszerben kiváló nyomásindikátor rutil, sem a nagy metamorf fokot jelző kianit nem jelenik meg bennük. A kőzetben található Ti-fázis az ilmenit, ami Domino modellezés alapján az adott kémiai összetétel mellett $\mathrm{P}<6,5$ kbar-on stabil. A kőzetalkotó Mg-gazdag klorit elméleti felső stabilitási határa $\mathrm{T}<600^{\circ} \mathrm{C}$ (LANARI et al. 2014). Bár az amfibolitokat termobarometriai becslésre nem használtuk, ásványos összetételük (epidot, titanit jelenléte) alátámasztja a kloritos biotitgneiszek alapján becsült, az amfibolit fáciesen belüli viszonylag kis hőmérsékletú $P-T$-intervallumot. A földpát szemcseméret termométer alapján a deformált szemcsék statikus rekrisztallizációjának hőmérséklete $\sim 510^{\circ} \mathrm{C}$, számottevően alacsonyabb a felső zónában tapasztaltnál.

Mindkét szomszédos zóna fejlődésétől szignifikánsan eltér a közbülsô, dolomitmárvány-zóna metamorf fejlődése. Minthogy a kőzetben a legnagyobb fokú metamorf mészszilikát ásvány a talk, a metamorfózis $T_{\text {max }}$ értéke DOMINO modellezés eredménye alapján nem haladhatta meg a $400{ }^{\circ} \mathrm{C}$-t, feltételezhetôen ennél is alacsonyabb volt. A kisfokú metamorf átalakulást támasztja alá a dolomitszemcsék deformációjának jellege is. PAPP et al. (2017) a dolomitmárvány mikroszöveti elemzése során II. és IV. típusú deformációs

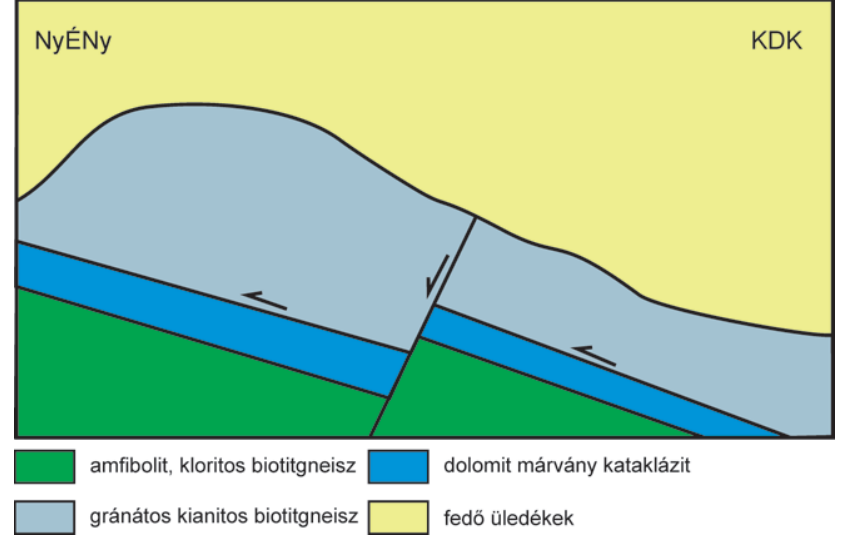

11. ábra. A Dorozsma terület idealizált felépítése kőzettani és lyukgeofizikai adatok alapján. Az egyes blokkokat a fő felépítő kőzettípus jelöli

Figure 11. Idealized structure of the Dorozsma basement area based on petrological and well-log data. Each block is named after its basic lithology, chlorite biotite gneiss, dolomite marble cataclasite and garnetiferous kyanite biotite gneiss dolomit ikresedést azonosítottak (BURKHARD 1993, FERILL et al. 2004 alapján), ami T $>250{ }^{\circ} \mathrm{C}$ hőmérsékleten lezajlott deformációra utal. Másrészt a deformált kvarc- és dolomitszemcsék statikus rekrisztallizációjának teljes hiánya $T$ $<450{ }^{\circ} \mathrm{C}$ hómérsékletet bizonyít.

Összefoglalóan, Dorozsmán lapos szögú, töréses deformációs térben kialakult kataklázos nyírási zóna mentén, kisebb metamorf fokú zóna fölött, nagy metamorf fokú blokk található (11. ábra). Erdélyi-középhegységi analógiák alapján (REISER et al. 2017a, b) feltételezhetô, hogy a dolomitmárvány kataklázit zóna az alpi takarórendszer valamely, aljzaton belüli takarójának, pikkelyének bázisát alkotja.

\section{Algyő}

Az Algyői magaslaton (HoRvÁTH \& ÁRKAI 2002, LELKESFELVÁRI et al. 2005, KONDOR \& M. TóTH 2021) nagyszámú fúrás hatolt a metamorf aljzatba, azonban mindegyik csak sekély mélységben harántolta azt. Ezen a területen a korábban látott lyukgeofizikai alapú litológiai azonosítás lehetôsége nem biztosított. Így, bár a kőzettípusok térképi elhelyezkedése tanulmányozható, függóleges kapcsolatrendszerük értelmezésére nincs mód.

A korábbi leírásokat némileg egyszerúsítve, módosítva, Algyőn öt fő kőzettípus azonosítható, melyek térképileg négy blokkban jelennek meg. A leggyakoribb típus, mely a hát északi és déli területeit alkotja, gránátos, kianitos biotitgneisz (12. ábra, a). Megjelenésében, petrográfiai tulajdonságaiban hasonló a Dorozsmán bemutatott litológiai típushoz. Az M1 metamorf paragenezist szintén gránát és rutil, míg az M2-t gránát, kianit és ilmenit jellemzi. Szintén jellemző a kőzet retrográd úton történt milonitosodása, a földpát képlékeny deformációjával. Ugyanebben a zónában néhány fúrás gránátos amfibolitot tárt fel, melyek minden esetben együtt jelenik meg a biotitgneisszel.

A kristályos hát középső területeit epidotgneisz, kloritpala és zöldpala alkotja, amint erre már a korai elemzések is rámutattak (,közbeékelődött kisfokú képződménytömeg” SZEDERKÉNYI 1984). Az epidotgneisz szöveti megjelenése és geokémiai tulajdonságai alapján ortogneisz. A mintákban általános a mirmekites földpátszemcsék, a poligonális szemcsehalmazok és az idiomorf járulékos ásványszemcsék megjelenése. A nagy méretű epidot és/vagy klinozoizit porfiroblasztok elnyíródtak a gneiszes foliáció mentén (12. ábra, b). A kloritpalát Chl+Qz+Fp+Cal+Epi paragenezis jellemzi, a kloritszemcsék peremén helyenként biotit mint a maximális metamorf fokot jelző index ásvány is megjelenik (12. ábra, c). Zöldpalát két fúrás tárt fel; mindkét esetben kloritpalával együtt jelenik meg. Bár nem szoros értelemben a (regionális) metamorf fejlődéshez kapcsolódik, de a felépítés és fejlődéstörténet szempontjából kulcskérdés, hogy a kloritpalamintákban általános a posztkinematikus szöveti helyzetben megjelenő, szulfidos és esetenként oxidos (pirit, kalkopirit, magnetit) ércásványok, valamint nemérces fázisok (pl. sziderit) hintett, esetleg teléres megjelenése propilites felülbélyegzésre utalva (12. ábra, d). 

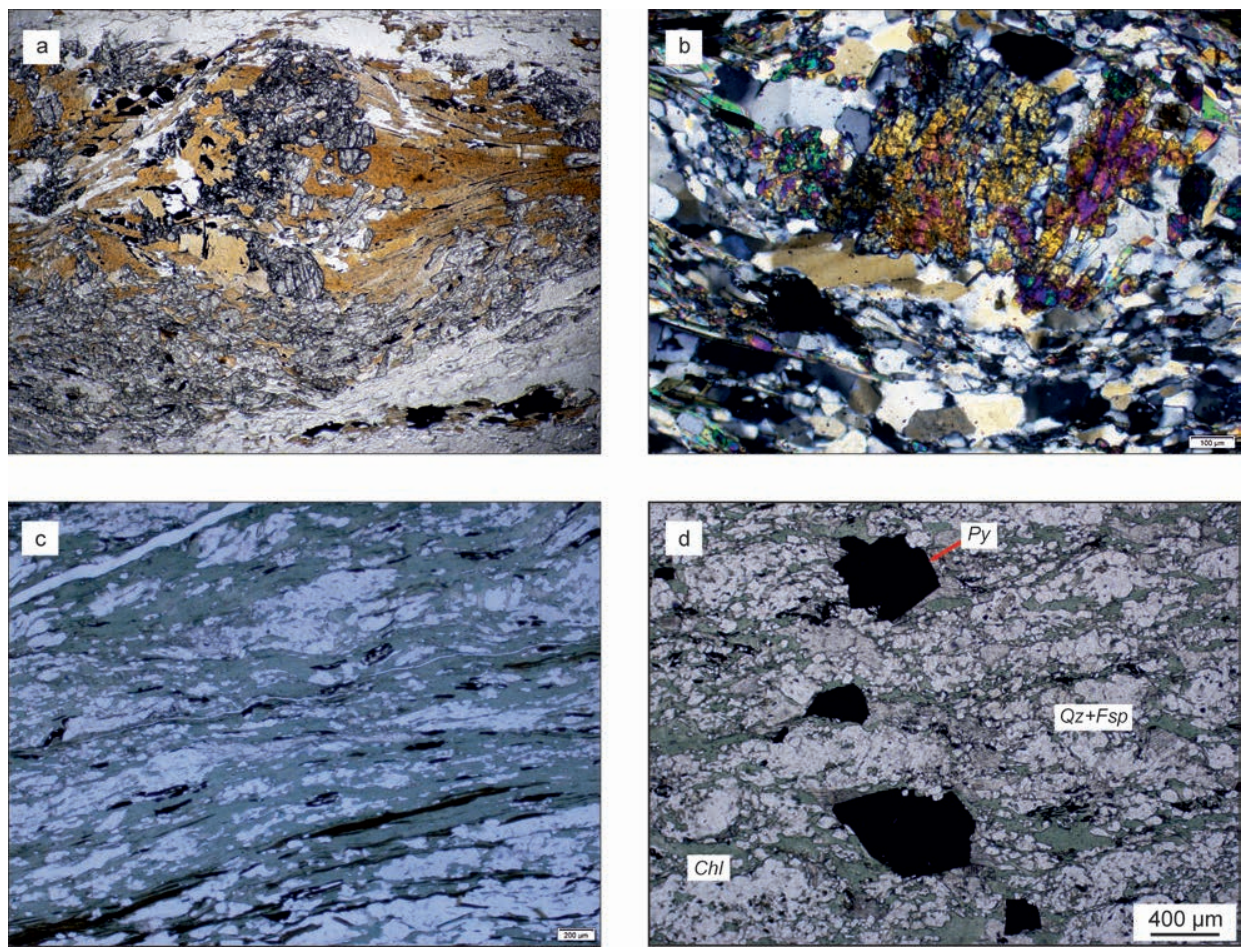

12. ábra. Az Algyő terület jellemző kőzettípusai. a) a gránátos, kianitos biotitgneisz jellemző szöveti képe (1N), b) elnyírt epidot porfiroblasztok epidotos ortogneiszben $(+\mathrm{N})$, c) a kloritpala jellemző szöveti képe $(1 \mathrm{~N})$, d) posztkinematikus piritszemcsék kloritpalában (1N).

Figure 12. Characteristic metamorphic lithologies of the Algyö basement area. a) typical texture of the garnetiferous kyanite biotite gneiss $(P P L), b$ ) sheared epidote porphyroblast in epidote orthogneiss $(X P L), c)$ typical texture of the chlorite schist $(P P L), d)$ postkinematic pyrite grains in chlorite schist (PPL)

HORVÁTH \& ÁRKAI (2002) termobarometriai számításai szerint a gránátos, kianitos gneiszben az M1 esemény 520$560{ }^{\circ} \mathrm{C} 8,2-10,1$ kbar viszonyok között zajlott, majd a kianit keletkezésével járó M2 eseményt dekompresszióval járó felfútés eredményezte $\left(570-650{ }^{\circ} \mathrm{C}, 6,0-9,0 \mathrm{kbar}\right)$. Az M2 paragenezist alkotó gránát, biotit és kianit kis szemcsemérete alapján TWQ modellezésre alapozva KONDOR \& M. TóTH (2021) felvetik a második metamorf esemény kontakt metaszomatikus eredetét is. Eszerint a maximális metamorf fokot jelző kianit progresszív hidratációs reakció (Grt+Kfs+ $\mathrm{H}_{2} \mathrm{O}=\mathrm{Qz}+\mathrm{Ky}+\mathrm{Bt}$ ) eredményeként keletkezett. A második metamorf esemény kontakt eredetét HoRvÁTH \& ÁrKAI (2002) is valószínúsítik. A kőzet korai metamorfózisának kora gránát Sm-Nd adatok alapján 273 \pm 7 M év (LELKESFelvári et al. 2003). A másodlagos muszkovitok Ar-Ar kora (68,4-84,3 Mév, BALOGH \& PéCSKAY 2001, 82-95 M év, LELKES-FeLVÁRI et al. 2003) alapján egyértelmú a kôzettestet ért alpi felülbélyegzés, ami, egyetértve HoRvátH \& ÁRKAI (2002) értékelésével, feltehetôen a kontakt metaszomatózis hatását mutatja.

$\mathrm{Az}$ epidotos ortogneisz szöveti megjelenése és a TWQ modellezés eredménye alapján zöldpala fáciesben $\left(\sim 400^{\circ} \mathrm{C}\right)$ metamorfizálódott a kiindulási granitoid protolitból. A kốzet diagnosztikus ásványa, az epidot keletkezése a retrográd $\mathrm{Kfs}+\mathrm{Pl}+\mathrm{H}_{2} \mathrm{O}=\mathrm{Ms}+\mathrm{Qz}+\mathrm{Czo}+\mathrm{Ab}$ reakció eredménye lehet (KONDOR \& M. TóTH 2021). A kloritpala szintén kisfokú képződmény, azonban keletkezése a klorit utáni biotit megjelenése alapján egyértelmúen progresszív metamorfó- zishoz köthetô. Az epidotos ortogneisz és a kloritpala evolúciója mindezek alapján alapvetően eltér egymásétól, hiszen, bár mindkettő kisfokú képződmény, az egyik retrográd, a másik progresszív zöldpala fáciesú metamorfózis eredménye. Eltérô fejlődésüket igazolja a kloritpalát ért intenzív posztmetamorf propilites felülbélyegzés is, mely az epidotos ortogneisz blokkban teljesen hiányzik, igazolva, hogy a két kőzettest a metaszomatikus hatást követô szerkezeti mozgások eredményeként került egymás mellé. Minthogy a régióban meghatározó, a muszkovit korok alapján valószínúsíthetôen kréta korú magmás hatók a késô kréta banatit intrúziók, már SZEDERKÉNYI (1984) is ehhez a magmás aktivitáshoz kötötte az algyői kőzeteken azonosítható, különböző jellegú metaszomatikus hatásokat. Amennyiben az epidotos ortogneisz és a kloritpala blokkjai között feltételezhetó szerkezeti határ ennél fiatalabb, akkor nem zárható ki, hogy az a terület neogén fejlődését meghatározó magkomplexum (PosGAY et al. 1996) szerkezetéhez kapcsolódik (13. ábra). Mindazonáltal a kôzettípusok térképi elrendeződése alapján vázolt vertikális kép megfelelố geofizikai információ hiányában ennél pontosabban nem rekonstruálható.

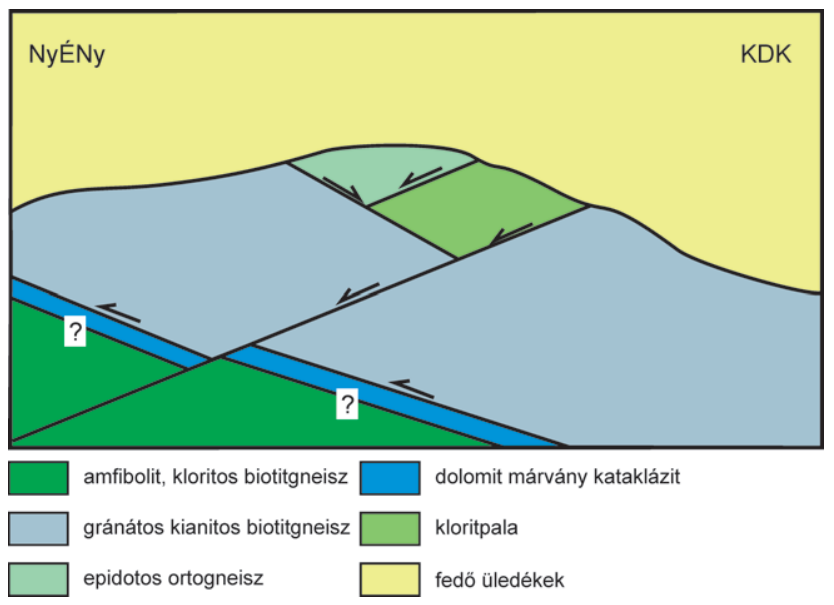

13. ábra. Az Algyő terület idealizált felépítése kőzettani adatok alapján

Figure 13. Idealized structure of the Dorozsma basement area based on petrological data. Each block is named after its basic lithology, garnetiferous kyanite biotite gneiss, chlorite schist and epidote orthogneiss 


\section{Értelmezés, következtetések}

A Pannon-medence, s így az Alföld fiatal üledékekkel fedett medencealjzatáról alkotott korai elképzelések a geofizikai kutatások eredményeként alapvetően megváltoztak az 1960-as, 70-es években. A korábbi, fél évszázadon keresztül általánosan elfogadott rideg, statikus, ,köztes tömeg" modellt folyamatosan bővülő tartalommal egy heterogén felépítésú, dinamikus medencealjzat képe váltotta fel (Stegena 1964, HoRvÁth 2003). A szénhidrogén-kutatás fejlődésével párhuzamosan egyre bővülő mélyfúrásos tevékenység során felszínre hozott aljzati fúrómagok aprólékos kőzettani, mikroszerkezeti és geokronológiai elemzésének eredményeként mára megállapíthatjuk, hogy az Alföld metamorf aljzata kisléptékben, akár néhány $10 \mathrm{~km}^{2}$ területeket vizsgálva is meglehetősen heterogén mind felépítését, mind fejlődését tekintve. Ugyanakkor a kisléptékben megnyilvánuló változatosság felismerhető mintázatai lehetőséget biztosítanak a rekonstruált egységek nagyobb távolságra történő laterális korrelációjára is (14. ábra).

A fent vázlatosan bemutatott aljzati hátak mindegyikére jellemző az elsősorban vertikális tagolódásukban megnyilvánuló mozaikos felépítés. Igazolható, hogy azokat eltérő kőzettani felépítésú és metamorf fejlődésû kôzetblokkok építik fel, ezért közöttük posztmetamorf szerkezeti zónák azonosíthatók. Az egységek és esetenként az azokat elválasztó szerkezetek petrológiai tulajdonságaik mellett kőzet- fizikai jellegükben is eltérnek egymástól, így fúrás mentén azonosíthatók, ami lehetôvé teszi a pontbeli kőzettani információ kiterjesztését az egy, majd a kettő, végül a három dimenzióba. Ezen bélyegek alapján jellegzetes, kőzettest léptékû szerkezeti mintázatok ismerhetôk fel a bemutatott területeken. Ezek a mintázatok azon túl, hogy a lehetôségekhez mérten pontos képet adnak az adott részterület belsô szerkezetéről, megfelelő alapot nyújtanak a korábbiaknál megalapozottabb térbeli korrelációs munka elvégzéséhez, $\mathrm{s}$ a fó szerkezeti egységek kijelöléséhez. Eredményeink lehetôvé teszik, hogy újraértelmezzük, pontosítsuk az Alföld aljzatát felépítő, egymástól eltérô és belső szerkezetükben is rendkívül heterogén fő metamorf egységeket. Ez a kőzettani-szerkezeti rekonstrukció egyúttal a korábbinál biztosabb alapot nyújt az Alföld metamorf aljzatának litosztratigráfiai beosztása során is. Eredményeink alapján a korábban alkalmazott, alapvetően területorientált komplexumbesorolási gyakorlat helyett a megállapított szerkezeti jellegeket is figyelembe vevő, új litosztratigráfiai tagolásra teszünk javaslatot. A litosztratigráfiai egységek elnevezésére, bár szinte minden esetben lényegesen megújult tartalommal, igyekeztünk felhasználni a korábbi nevezéktan fontos elemeit (FüLÖP 1994).

A Jánoshalmától Mezôsas-Furtáig minden vizsgált területen a legalsó ismert szerkezeti helyzetben általánosan jellemzó ortogneisz zóna (Jánoshalmai Ortogneisz Komplexum, 14., 15. ábra) fejlődéstörténetét ZACHAR \& M. TóTH

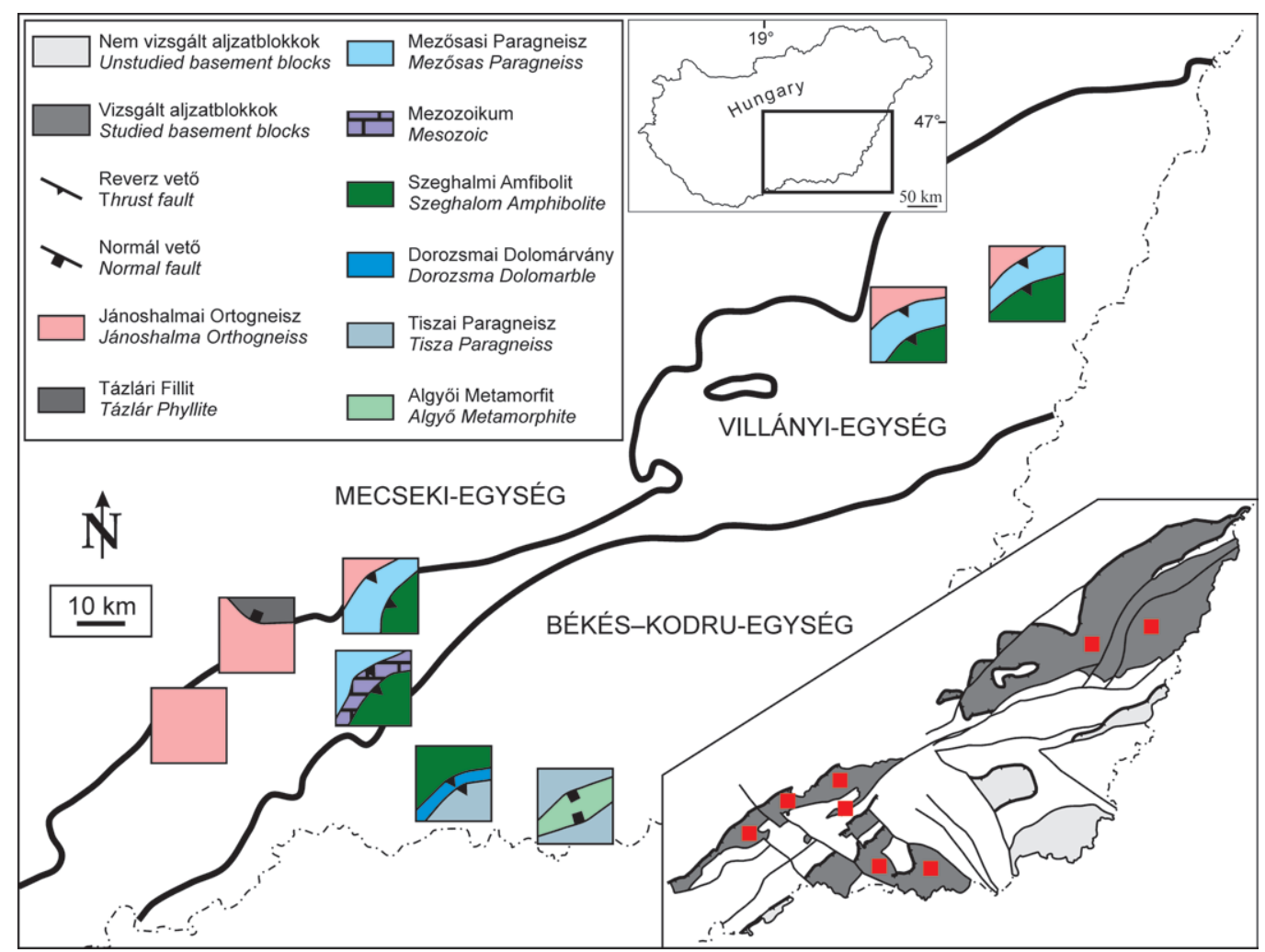

14. ábra. Az eltérő fejlődésű metamorf egységek vázlatos térképi megjelenése a részletesen elemzett aljzati mintaterületeken (alaptérkép HAAS et al. 2010, 2014 alapján; v.ö. 1. ábra)

Figure 14. Sketch maps of the metamorphic units with different evolutions in the studied basement areas (base map after HAAS et al. 2010, 2014; c.f. Figure 1) 
ÉÉNy

DDK

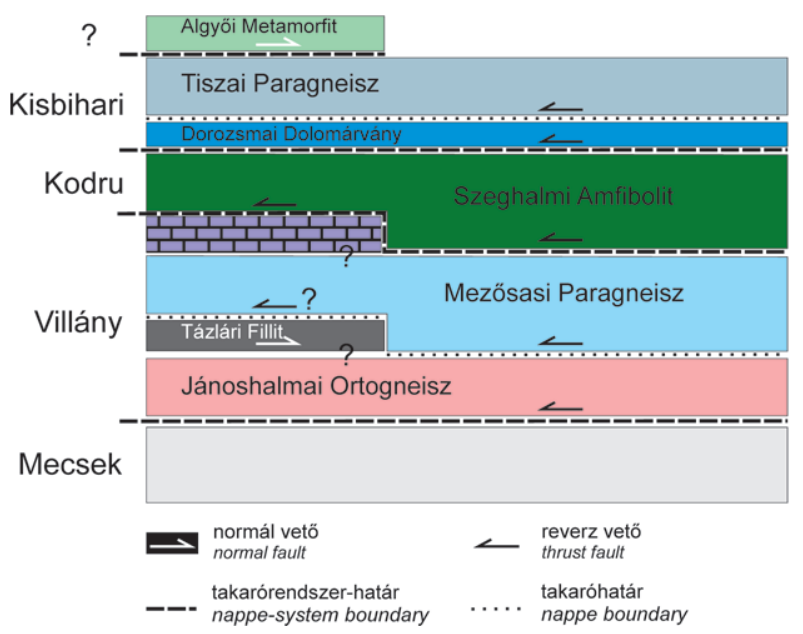

15. ábra. Az Alföld metamorf aljzatának javasolt litosztratigráfiai egységei a vizsgált területeken. A takaróhatárok definiálása a szomszédos blokkok eltérő metamorf fejlődése alapján történt. A takarórendszerekbe történő besoroláskor korábbi munkákat és erdélyi-középhegységi analógiákat vettünk figyelembe Figure 15. Suggested lithostratigraphic units of the metamorphic basement in the Great Hungarian Plain. Nappe fronts are defined based on different metamorphic evolutions of the neighbouring realms. When defining nappe system fronts, we appreciated the previous literature and analogies from the Apuseni Mts

(2004), majd M. Tóth \& SCHuberT (2018) foglalta össze. Mivel az ortogneiszben az összes lelőhelyen megtalálható, különböző eredetű és összetételú xenolit (eklogit, granulit, szerpentinit, amfibolit, márvány) és xenokristály típusok metamorf fejlődése szélsőségesen eltér egymásétól, korai evolúciójuk nem értelmezhetô közös geodinamikai modellben. Másrészt viszont a legtöbb kőzetzárvány esetében igazolható a maximális metamorf fokot követően kisfokú körülmények között (zöldpala fácies) végbement felülbélyegzés (16. ábra, a). Mindezek miatt a feltételezett fejlődési modell szerint az egykori granitoidolvadék a retrográd átalakuláson átesett, nagyon különböző kőzeteket tartalmazó összlet(ek)en áthaladva azokból kisebb-nagyobb kőzettesteket xenolitként hozott magával. Az ezzel szinkron izobár felfútés ( $\mathrm{T} \geq \sim 680^{\circ} \mathrm{C}$ és $\mathrm{P} \sim 3 \mathrm{kbar}$ ) hatása több xenolittípuson igazolható (16. ábra, a). Az ortogneisz mindezek után a granitoidtest metamorfózisával, a hőmérsékleti relaxáció folyamán (560-600 ${ }^{\circ} \mathrm{C}$ és $\sim 3 \mathrm{kbar}$ ) alakult ki ( 16 . ábra, b). További kiemelkedés (kb. $430{ }^{\circ} \mathrm{C}$ ) során végbement képlékeny deformáció hatására a kőzettest jellemzően lapos nyírási zónák mentén milonitosodott.

Ezt a fejlődési modellt az ortogneisz koradatai is megerôsítik. A legidősebb amfibolit xenolitok amfibol K-Ar kora átlagosan 334+13 M év, míg az ortogneisz biotitszemcséinek és az izotóp-geokronológiai szempontból felülírt

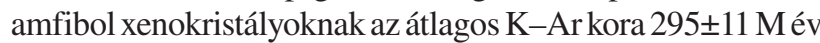
és 297£11 M év, jóval fiatalabb a bezárt kőzetzárványok koránál. A szeghalmi ortogneisz milonit másodlagos muszkovitszemcséin mért Ar-Ar kor 280ะ11 M év (BALOGH et al. 2009), ami jelzi a a posztorogén exhumáció során történt képlékeny deformáció korát. Minthogy az ortogneisz-zóna kőzetei az összes vizsgált területen hasonló viszonyok között, kb. $430{ }^{\circ} \mathrm{C}$-on a retrográd út során milonitosodtak, ezért a koradatok által jelzett perm eseményt regionális jelentôségúnek feltételezzük.

Az ortogneisz-egység fölött, vastag, töréses szerkezeti határ mentén Szanktól kelet felé követhető képződmény a polimetamorf (16. ábra, c) gránátos, sillimanitos biotitgneisz (Mezősasi Paragneisz Komplexum, 14., 15. ábra). Metamorf

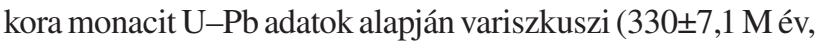
BALOGH et al. 2009). A kőzetből szeparált cirkonszemcsék hasadványnyom kora középső jura, ami a Pennini-óceán kinyílásához kapcsolódó termális hatásra, s így az egykori litoszféra számottevő kivékonyodására utalhat. Az ortogneisz és a biotitgneisz által jellemzett kőzetblokkok határát alkotó kataklázos nyírási zóna így szükségképpen már ezt követően, a litoszféra sekély helyzetű tartományában, töréses rezsimben keletkezett, hasonlóan a biotitgneisz és a fölötte elhelyezkedő amfibolit blokk (Szeghalmi Amfibolit Komplexum, 14., 15. ábra) szintén kataklázos határához. Lyukgeofizikai alapú kôzetváz-rekonstrukció alapján e térképezhetô, töréses eredetú szerkezetek közel délkeleti dőlésû síkokat definiálnak. A paragneiszétől eltérő metamorf fejlődésú (16. ábra, d) Szeghalmi Amfibolit alsó kataklázos határának juránál fiatalabb korát szintén bizonyítja a Csólyospálos-K területen az amfibolit megjelenése nem metamorf, triász-jura karbonátos rétegsorok fölött. Mindezek alapján, a Szanktól Mezősas-Furtáig az eltérő metamorf fejlődésú egységeket (és helyenként mezozoos üledékes összleteket) elválasztó töréses szerkezeti zónákat aljzaton belüli alpi takaróhatárokként értelmezzük.

A három alpi metamorf takaró rendszerébe nem illeszkedik a kizárólag Kiskunhalas-Tázlár területen nyomozható, fillittel, mészfillittel jellemzett önálló szerkezeti egység (Tázlári Fillit Komplexum, 14., 15. ábra). Metamorf fejlődéstörténete egyetlen más képződményével sem rokonítható (16. ábra, e); az alatta elhelyezkedő ortogneisszel feltehetően extenziós feszültségmezőben kialakult, vastag, milonitos zóna mentén érintkezik. Ez a szerkezeti kontaktus a kataklázittal, vetőbreccsával jelzett takaróhatároknál szükségképpen nagyobb hőmérsékleten (mélységben) és eltérő geodinamikai helyzetben alakult ki. A lyukgeofizikai adatok alapján történt kőzetváz-rekonstrukció értelmében a kisfokú képződmények bázisa északi dőlésû, ellentétben az alpi takarók délies dőlésével. Mindezeket, valamint az ortogneisz milonit másodlagos muszkovitszemcséinek perm korát figyelembe véve a Tázlári Fillit az ortogneisz fölött megőrződött variszkuszi takaróroncsként vagy extenziós allochtonként értelmezhetô.

Az Alföld DK-i területén részletesen elemzett két részterület felépítésében szintén markánsan különböző fejlődésű metamorf egységek vesznek részt, melyeket szükségképpen posztmetamorf szerkezeti határok választanak el egymástól. A dorozsmai területen a közepes fokú amfibolitra a kisfokú (16. ábra, f) dolomitmárvány kataklázitzóna (Dorozsmai Dolomárvány Komplexum; 14., 15. ábra) mentén rátolt nagyfokú gránátos, kianitos gneisz egység (Tiszai Paragneisz; 14., 15. ábra) a korábbiakhoz hasonlóan 

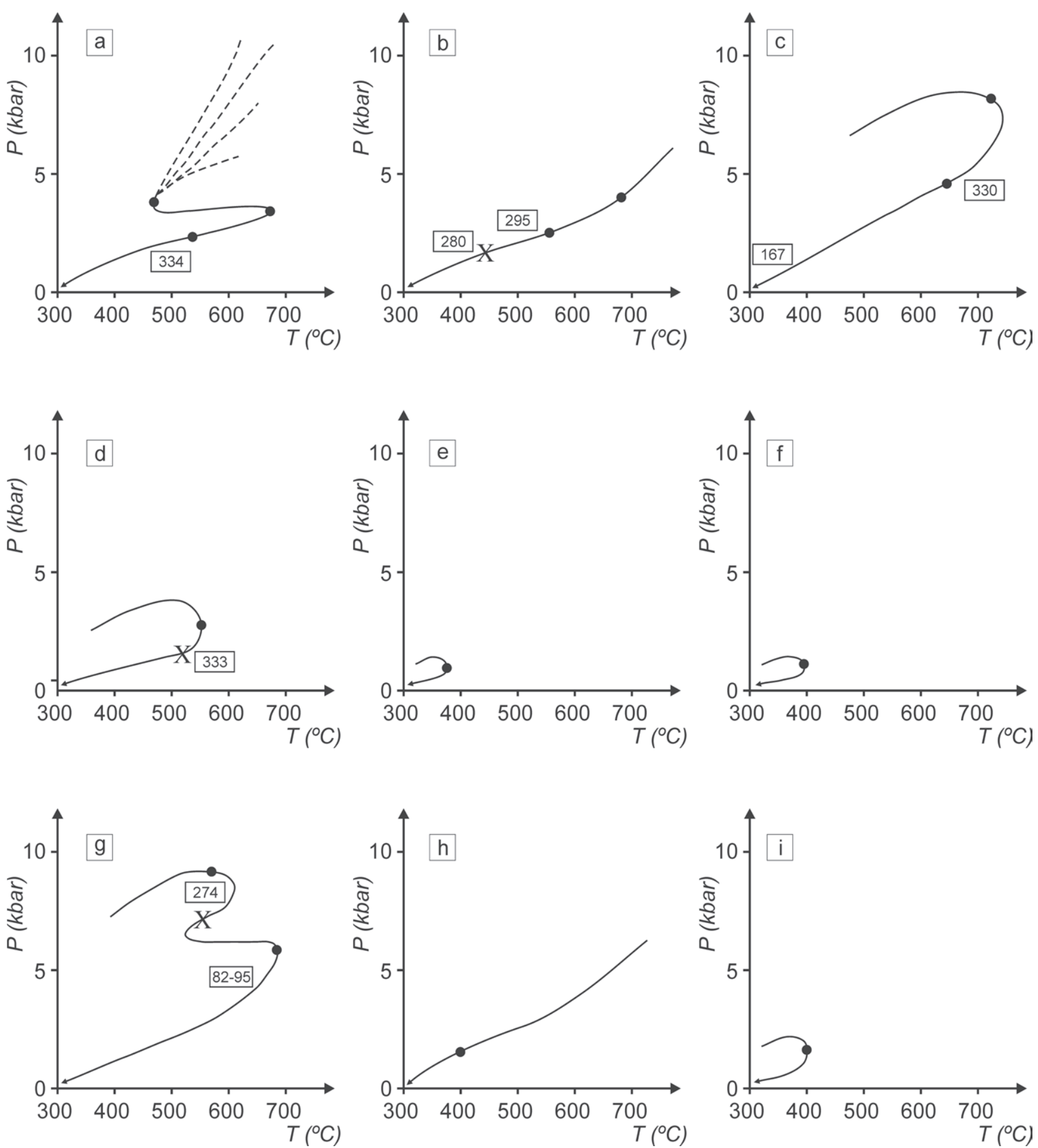

16. ábra. A fő szerkezeti egységek egyszerűsített P-T-d-t evolúciója. Fekete pontok jelzik a termobarometriai számolással igazolt P-T állapotokat, X jelzi a milonitos deformációs események igazolt hőmérsékletét. A számok a különböző geokronológiai mérések eredményeit mutatják (M év). a) xenolitok az ortogneiszben; b) Jánoshalmai Ortogneisz; c) Mezősasi Paragneisz; d) Szeghalmi Amfibolit; e) Tázlári Fillit; f) Dorozsmai Dolomárvány; g) Tiszai Paragneisz; h) Algyői Metamorfit (epidotos ortogneisz); i) Algyői Metamorfit (kloritpala)

Figure 16. Simplified P-T-d-t evolution of the major structural units. Black dots denote results of the quantitative thermobarometry, $X$ marks justified temperatures of mylonitic deformation events. Numbers show age data in Ma measured using different methods. a) xenoliths in the orthogneiss; b) Jánoshalma Orthogneiss; c) Mezösas Paragneiss; d) Szeghalom Amphibolite; e) Tázlár Phyllite; f) Dorozsma Dolomarble; g) Tisza Paragneiss; h) Algyö Metamorphite (epidote gneiss); i) Algyö Metamorphite (chlorite schist)

takarós felépítést sugall. Ezt alátámasztja a három kőzettest petrofizikai adatokon alapuló térbeli kiterjesztésének eredménye is (M. Tóth \& VARGÁNÉ TóTH 2020).

Felmerül a kérdés, hogy vajon van-e kapcsolat a Dorozs- mán legalsó és a Szanktól kelet felé bemutatott területeken egységesen legfelső szerkezeti helyzetben található, amfibolittal jellemzett egységek között. A szanki és (a Dorozsmától nyugatra fekvő) öttömösi fúrások amfibolitmintáinak 
számos kőzettani hasonlóságára már SzEPESHÁzy (1966) és MeszÉnA (1973) is felhívta a figyelmet. A rekonstruálható protolit mindkét területen bázikus vulkanoszediment összlet lehetett az amfibolit, amfibolos biotitgneisz és biotitgneisz akár kézipéldány léptékben megfigyelhető váltakozása alapján. Az amfibolit mindkét területen monometamorf képződmény, nagyon hasonló ásványos összetétellel és analóg maximális metamorf átalakulási körülményekkel $\left(\sim 570{ }^{\circ} \mathrm{C}, \sim 4 \mathrm{kbar} ; 16\right.$. ábra,$\left.d\right)$. Mindezen érvek, valamint az északi amfibolitpászta legdélibb előfordulása (Csólyospálos) és a dorozsmai terület közötti alig 10 km-es távolság alapján lehetséges, hogy a két amfibolitdomináns kőzetblokk ugyanazon szerkezeti egységhez tartozik (Szeghalmi Amfibolit; 14., 15. ábra).

Összevethetô ásványos összetételük, metamorf, valamint posztmetamorf fejlődésük alapján (16. ábra, g) a dorozsmai felsố egység (Tiszai Paragneisz Komplexum, 14., 15. ábra) azonosítható az algyői szerkezet fő tömegét adó gránátos, kianitos gneisszel. Hasonló kőzettani, valamint geokronológiai indokok alapján LelKesné FELVÁRI et al. (2005) kiterjesztették ezt az egységet a környező (Forráskút, Üllés stb.) fúrások által feltárt aljzatra is. A kizárólag az algyői magaslat központi területén előforduló, egymással ismeretlen szerkezeti kapcsolatban lévő, különböző fejlődésú kisfokú kőzetek (összefoglalóan Algyői Metamorfit Komplexum, 14., 15., 16. ábra, $h, i)$ megjelenése mindazonáltal nem értelmezhető a korábbiakkal analóg módon alpi takaróként. Ebben az egységben a takarók kora kréta kialakulásánál feltehetően fiatalabb metaszomatikus felülbélyegzés hatása is rekonstruálható, ami nem jellemzô a környezô gránátos, kianitos gneiszben. Ez igazolja, hogy a Tiszai és az Algyői Komplexum (15. ábra) krétánál fiatalabb szerkezeti mozgások eredményeként kerülhetett egymás mellé (KONDOR \& M. TóTH 2021). Korábbi szeizmikus értelmezések (PosGAY et al. 1996) igazolták, hogy az algyői kristályos hát és az annak nyugati folytatását alkotó kristályos aljzat a Pannon-medence kialakulásával egyidejú metamorf magkomplexum rendszert alkot (TARI et al. 1999). Ez alapján feltételezzük, hogy a kisfokú egység határait az algyői szerkezeten belüli kainozoos extenziós szerkezetek alkotják.

Bár jelen dolgozatban nem vizsgáltuk, ismert, hogy a Jánoshalmától Mezôsas-Furtáig húzódó ortogneisz-zónán belüli tektonikai ablakban (PAP 1990), illetve a zónától északra (BÉRCZINÉ MAKK et al. 1997) a metamorf kőzetek alatt Mecseki-típusú, nagyon kisfokú metamorf (ÁRKAI et al. 1998), valamint nem metamorf mezozoikumot (pl. Mecsekjánosi Bazaltot) tártak fel a fúrások azt igazolva, hogy az ortogneisz egység is alpi takarós helyzetben van. Az amfibolittal jellemzett metamorf takaró alatti mezozoos képződményeket a csólyospálos-kömpöci területen ÁRKAI et al. (2000) Villányi-típusúnak értékelték. Ezek alapján a Jánoshalmai Ortogneiszt és a Mezősasi Paragneiszt a Villányi-, míg a Szeghalmi Amfibolitot a Kodru-takarórendszerbe soroljuk. Ezt a besorolást erósíti, hogy az Erdélyiközéphegységben a Kodru-rendszerbe sorolt egyetlen, dominánsan metamorf kőzetekből álló takaró (Várasfenesitakaró) fő kőzettípusa szintén variszkuszi korú ortoamfibolit kevés gneisszel és csillámpalával (PANĂ et al. 2002). Erdélyi-középhegységi megfigyelések alapján alpi amfibolit fáciesú metamorf felülbélyegzés a Kisbihari-takarórendszerben fordul elô, míg a Kodruban nem ismert (RESIER et al. 2017a). Ez alapján nem zárható ki, hogy a Szeghalmi Amfibolit fölötti gránátos, kianitos Tiszai Paragneisz már a Kisbihari-takarórendszerhez tartozó takaróroncs (15. ábra), s a dolomárvány kataklázit ennek talpi lenyesési felületét definiálja. Kérdéses ugyanakkor az Algyőn legmagasabb szerkezeti helyzetben megjelenő kisfokú kőzetek szerkezeti besorolása. Minthogy ezek az egységek jelenleg már nem az eredeti alpi takarós helyzetükben találhatók, a kérdés megválaszolása további részletes korrelációs munkát igényel.

Az eddigi vizsgálatokba bevont és itt bemutatott metamorf aljzati egységeken túl vannak további vizsgálandó objektumok az Alföld aljzatában, melyek számottevően árnyalhatják, bonyolíthatják a jelenlegi képet. Így, többek között, az Álmosd-Kismarja, a Sarkadkeresztúr, a Pusztaföldvár, az Ásotthalom környéki mélyfúrások maganyagának részletes feldolgozására bizonyosan szükség lesz a tarka metamorf aljzati mozaik még részletesebb kirakásához.

\section{Köszönetnyilvánítás}

A kézirat alapos javításáért, valamint a sok előre vivő gondolatért, tanácsért a szerzők köszönetet mondanak CsOnTos Lászlónak, KoROKNAI Balázsnak és KIRÁLY Editnek.

\section{Irodalom -References}

AGócs, Á. 2013: Apatit generációk és fluidumzárvány-együtteseik vizsgálata mészszilikátban (Szank-60. fúrás). - Kézirat, Diplomamunka, SZTE, $47 \mathrm{p}$.

Aoya, M., Kouketsu, Y., Endo, S., Shimizu, H., Mizukami, T., Nakamura, D. \& Wallis, S. 2010: Extending the applicability of the Raman carbonaceous-material geothermometer using data from contact metamorphic rocks. - Journal of Metamorphic Geology 28/9, 895-914. https://doi.org/10.1111/j.1525-1314.2010.00896.x

ÁRKAI P. 1991: Kishőmérsékletû regionális metamorfózis (alkalmazások magyarországi példákon). - Kézirat, MTA Doktori értekezés, 190 p.

ÁRKAI, P. 1993: The distinction between low-T retrograde metamorphism and weathering + burial diagenesis of the gneiss and mica schist basement complex, Great Plain, Hungary: A novel use of illite "crystallinity". - Neues Jahrbuch für Mineralogie, Monatshefte 8, 337-351. 
ÁRKAI, P. 2001: Alpine regional metamorphism in the main tectonic units of Hungary: A review. - Acta Geologica Hungarica 44/2, 329_ 344.

ÁRKAI, P., BÉRCZI-MAKK, A. \& HAJdU, D. 1998: Alpine prograde and retrograde metamorphism in an overthrusted part of the basement, Great Plain, Pannonian Basin, eastern Hungary. - Acta Geologica Hungarica 41/2, 179-210.

Árkai, P., BALOGH, K. \& BÉrCZI-MAKK, A. 2000: Alpine low-T prograde metamorphism in the post-Variscan basement of the Great Plain, Tisza Unit (Pannonian Basin, Hungary). - Acta Geologica Hungarica 43/1, 43-63.

Balázs E., Cserepesné Meszéna B., Szili Gy. \& Nusszer A. 1985: Kísérlet az Alföld metamorf képződményeinek az Erdélyi középhegységgel való azonosítására. - Általános Földtani Szemle 21, 223-231.

Balázs, E., Cserepesné MeszénA, B., Nusszer, A. \& Szili Gyémánt, P. 1986: An attempt to correlate the metamorphic formations of the Great Hungarian Plain and the Transylvanian Central Mountains (Muntii Apuseni). - Acta Geologica Hungarica 29/3-4, 317-320.

BALOGH, K. \& PÉCSKAY, Z. 2001: K/Ar and Ar/Ar geochronological studies in the PANCARDI region. - Acta Geologica Hungarica 44/2-3, 281-299.

BALogh K., M. Tóth T., Dunkl I. \& SCherRer N. 2009: A polimetamorf aljzat geokronológiai viszonyai a Szeghalom és a MezősasFurta háton. - In: M. TóTH T. (szerk.): Magmás és metamorf képződmények a Tiszai Egységben. GeoLitera, 147-160.

BENCSIK, A. 2011: A szanki kristályos aljzat DK-i részének metamorf és poszt-metamorf fejlődéstörténete. - Kézirat, Diplomamunka, SZTE, pp. 51.

BÉRCZINÉ MAKK, A. 1998: Az Alföld és a Tokaji-hegység triász és jura képződményeinek rétegtana. In: BÉRCZI I. \& JÁMBOR Á. (szerk.): Magyarország geológiai képzódményeinek rétegtana. MOL Rt.,MÁFI, Bp. 281-298.

BÉRCZINÉ MAKK A., CsÁsZÁR G. \& Nusszer A. 1997: A Mecseki Zóna közép-alföldi mezozóos aljzatának sztratigráfiai értékelése és fejlődéstörténeti vázlata. - Földtani Közlöny 126/2-3, 185-207.

BERMAN, R. G. 1988: Internally-Consistent Thermodynamic Data for Minerals in the system $\mathrm{Na}_{2} \mathrm{O}-\mathrm{K}_{2} \mathrm{O}-\mathrm{CaOMgO}-\mathrm{FeO}_{2}-\mathrm{Fe}_{2} \mathrm{O}_{3}-\mathrm{Al}_{2} \mathrm{O}_{3}-$ $\mathrm{SiO}_{2}-\mathrm{TiO}_{2}-\mathrm{H}_{2} \mathrm{O}-\mathrm{CO}_{2}$. Journal of Petrology 29, 445-522. https://doi.org/10.1093/petrology/29.2.445

Berman, R. G. 1991: Thermobarometry using multi-equilibrium calculations: a new technique, with petrological applications. Canadian Mineralogist 29, 833-855.

Beyssac, O., Goffé, B., Chopin, C. \& Rouzaud, N. 2002: Raman spectra of carbonaceous material in metasediments: a new geothermometer. - Journal of Metamorphic Geology 20, 859-871. https://doi.org/10.1046/j.1525-1314.2002.00408.x

Beyssac, O., Goffé, B., Petitet, J.-P., Froigneux, E., Moreau, M. \& Rouzaud, J.-N. 2003: On the characterization of disordered and heterogeneous carbonaceous materials by Raman spectroscopy. - Spectrochimica Acta Part A, 59, 2267-2276. https://doi.org/ $10.1016 / \mathrm{s} 1386-1425(03) 00070-2$

Beyssac, O., Bollinger, L., Avouac, J-P. \& Goffé, B. 2004: Thermal metamorphism in the lesser Himalaya of Nepal determined from Raman spectroscopy of carbonaceous material. - Earth and Planetary Science Letters 225, 233-241. https://doi.org/10.1016/ j.eps1.2004.05.023

Bhattacharya, A., Mohanty, L., Maji, A., Sen, S. K. \& Raith, M. 1992: Non-ideal mixing in the phlogopite annite binary: constraints from experimental data on $\mathrm{Mg}$-Fe partitioning and a reformulation of the biotite-garnet thermometer. - Contributions to Mineralogy and Petrology 111, 87-93. https://doi.org/10.1007/bf00296580

Buda, Gy., PÁl-Molnár, E. \& Koller, F. 2012: Mafic enclaves in peraluminous Variscan granitoid in the Battonya Unit from Southeast Hungary. - Geologia Croatica 65/2, 243-253. https://doi.org/10.4154/gc.2012.15

BURKHARD, M. 1993: Calcite twins, their geometry, appearance and significance as stress-strain markers and indicators of tectonical regime: a review. - Journal of Structural Geology 15, 351-368. https://doi.org/10.1016/0191-8141(93)90132-t

CSEREPESNÉ MEsZÉNA B. 1978: A Kiskunhalas-Ny-3 szénhidrogénkutató fúrással feltárt alsópannóniai bazalt és proterozoi migmatit képződményekről. - Földtani Közlöny 108/1, 53-64.

CsEREPESnÉ MeszénA, B. 1983: Migmatite belts in the basement complex of the region between Danube and Tisza. - Anuarul Institutului de Geologie si Geofizica 61, 23-29.

CSEREPESNÉ MEsZÉNA B. 1985: A Duna-Tisza köze kristályos alaphegységének litosztratigráfiai felosztása. - Általános Földtani Szemle 21, 117-194.

CSEREPESNÉ MeszénA, B. 1986: Petrography of the crystalline basement of the Danube-Tisza Interfluve (Hungary). - Acta Geologica Hugarica 29/3-4, 321-339.

DE CAPITANI, C. 1994: Gleichgewichts-Phasendiagramme: Theorie und Software. - Beihefte zum European Journal of Mineralogy, 72. Jahrestagung der Deutschen Mineralogischen Gesellschaft 6, p. 48.

DE CAPITANI, C. \& BRown, T. H. 1987: The computation of chemical equilibrium in complex systems containing non-ideal solutions. Geochimica et Cosmochimica Acta 51, 2639-2652. https://doi.org/10.1016/0016-7037(87)90145-1

Ferill, D. A., Morris, A. P., Evans, M. A., Burkhard, M., Groshong, R. H. \& Onasch, C. M. 2004: Calcite twin morphology: a lowtemperature deformation geothermometer. - Journal of Structural Geology 25, 1521-1529. https://doi.org/10.1016/01918141(91)90029-i

Fiser-NAGY, Á. 2013: Complex evaluation of the Kiskunhalas-NE fractured metamorphic hydrocarbon reservoir. - PhD értekezés, Szegedi Tudományegyetem 115 p. https://doi.org/10.14232/phd.1900

Fiser-NAGY, Á. \& M. TóTH, T. 2012: Petrology and tectonic evolution of the Kiskunhalas-NE fractured hydrocarbon reservoir, South Hungary. - Central European Geology 55/1, 1-22. https://doi.org/10.1556/ceugeol.55.2012.1.1

Fiser-NAGY, Á., M. Tóth, T., VÁSÁRhELYI, B. \& Földes, T. 2013: Integrated core study of a fractured metamorphic HC-reservoir; Kiskunhalas-NE, Pannonian Basin. - Acta Geodaetica et Geophysica Hungarica 48/1, 53-75. https://doi.org/10.1007/s40328-012$0008-\mathrm{y}$

Fiser-NAGY, Á., VARGÁNÉ Tóth, I. \& M. TóTH, T. 2014: Lithology identification using open-hole well-log data in the metamorphic 
Kiskunhalas-NE hydrocarbon reservoir, South Hungary. - Acta Geodaetica et Geophysica Hungarica 49/1, 57-78. https://doi.org/ 10.1007/s40328-013-0037-1

FÜLÖP J. 1994: Magyarország geológiája. Paleozoikum II. - Akadémiai kiadó, Budapest, 447 p.

Gerya, T. V., Perchuk, L. L., Triboulet, C., Audren, C. \& Sez' Ko, A. I. 1997: Petrology of the Tumanshet Zonal Metamorphic Complex, Eastern Sayan. - Petrology 5, 503-533.

Graham, C. M. \& Powell, R. 1984: A garnet-hornblende geothermometer: calibration, testing, and application to the Pelona Schist, Southern California. - Journal of Metamorphic Geology 2, 13-31. https://doi.org/10.1111/j.1525-1314.1984.tb00282.x

Green, T. H. \& Hellmann, P. L. 1982: Fe-Mg partitioning between coexisting garnet and phengite at high pressure, and comments on garnet-phengite geothermometer. - Lithos 15, 253-266. https://doi.org/10.1016/0024-4937(82)90017-2

HAAS J., BudAi T., CSONTOS L., Fodor L. \& KonRÁd Gy. 2010: Magyarország pre-kainozoos földtani térképe, 1:500 000. - A Magyar Állami Földtani Intézet, Budapest.

HAAs J., BUdAI T. (szerk.), Csontos L., Fodor L., KonRÁD Gy. \& KoroKnai B. 2014: Magyarország prekainozoos medencealjzatának földtana. Magyarázó „Magyarország pre-kainozoos földtani térképéhez” 1:500 000). - Magyar Földtani és Geofizikai Intézet, Budapest.

Henry, D. J., Guidotti, C. V. \& Thomson, J. A. 2005: The Ti-saturation surface for low-to-medium pressure metapelitic biotite: Implications for Geothermometry and Ti-substitution Mechanisms. - American Mineralogist 90, 316-328. https://doi.org/10.2138/ am.2005.1498

Holland, T. J. B. \& Blundy, J. 1994: Non-ideal interactions in calcic amphibole and their bearing on amphibole-plagioclase thermometry. - Contributions to Mineralogy and Petrology 116, 433-447. https://doi.org/10.1007/bf00310910

Holland, T. J. B. \& Powell, R. 1985: An internally consistent thermodynamic dataset with uncertainties and correlations; 2, Data and results. - Journal of Metamorphic Geology 3, 343-370. https://doi.org/10.1111/j.1525-1314.1985.tb00325.x

Holland, T. J. B. \& Powell, R. 1990: An enlarged and updated internally consistent thermodynamic dataset with uncertainties and correlations; the system $\mathrm{K}_{2} \mathrm{O}-\mathrm{Na}_{2} \mathrm{O}-\mathrm{CaO}-\mathrm{MgO}-\mathrm{MnO}-\mathrm{FeO}-\mathrm{Fe}_{2} \mathrm{O}_{3}-\mathrm{Al}_{2} \mathrm{O}_{3}-\mathrm{TiO}_{2}-\mathrm{SiO}_{2}-\mathrm{C}-\mathrm{H}_{2}-\mathrm{O}_{2}$. - Journal of Metamorphic Geology 8, 89-124. https://doi.org/10.1111/j.1525-1314.1990.tb00458.x

Holland, T. J. B. \& Powell, R. 1998: An internally consistent thermodynamic data set for phases of petrological interest. - Journal of Metamorphic Geology 16, 309-343. https://doi.org/10.1111/j.1525-1314.1998.00140.x

HoRVÁth, F. 2003: A Pannon-medence földtani-geofizikai modellje. - Magyar Geofizika 45, 102-107.

Horváth, P. \& ÁrkaI, P. 2002: Pressure-temperature path of metapelites from the Algyő-Ferencszállás area, SE Hungary: Thermobarometric constraints from coexisting mineral assemblages and garnet zoning. - Acta Geologica Hungarica 45/1, 1-27. https://doi.org/10.1556/ageol.45.2002.1.1

Kelsey, D. E., White, R. W., Holland, T. J. B. \& Powell, R. 2004: Calculated phase equilibria in $\mathrm{K}_{2} \mathrm{O}-\mathrm{FeO}-\mathrm{MgO}_{2}-\mathrm{Al}_{2} \mathrm{O}_{3}-\mathrm{SiO}_{2}-\mathrm{H}_{2} \mathrm{O}$ for sapphirine-quartz-bearing mineral assemblages. - Journal of Metamorphic Geology 22, 559-578. https://doi.org/10.1111/j.15251314.2004.00533.x

KoHn, M. J. 2014: "Thermoba-Raman-try": Calibration of spectroscopic barometers and thermometers for mineral inclusions. - Earth and Planetary Science Letters 388, 187-196. https://doi.org/10.1016/j.epsl.2013.11.054

KoHN, M. J. \& SpEAR, F. S. 1991: Error propagation for barometers: 2. Application to rocks. - American Mineralogist 76, $138-147$.

KondoR, H. \& M. Tóth, T. 2021: Contrasting metamorphic and post-metamorphic evolutions within the Algyő basement high (Tisza Mega-unit, SE Hungary). Consequences on structural history. - Central European Geology in press

KRUHL, J. H. 2001: Crystallographic control on the development of foam textures in quartz, plagioclase and analogue material. International Journal of Earth Sciences 90, 104-117. https://doi.org/10.1007/s005310000170

KRUHL, J. H. \& NeGA, M. 1996: The fractal shape of sutured quartzgrain boundaries: application as a geothermometer. - Geologische Rundschau 85, 38-43. https://doi.org/10.1007/bf00192058

LANARI, P., WAGNER, T. \& VIDAL, O. 2014: A thermodynamic model for di-trioctahedral chlorite from experimental and natural data in the system $\mathrm{MgO}-\mathrm{FeO}-\mathrm{Al}_{2} \mathrm{O}_{3}-\mathrm{SiO}_{2}-\mathrm{H}_{2} \mathrm{O}$ : applications to $\mathrm{P}-\mathrm{T}$ sections and geothermometry. - Contributions to Mineralogy and Petrology 167/2, 1-19. https://doi.org/10.1007/s00410-014-1039-х

Lelkes-Felvári, Gy., Frank, W. \& Schuster, R. 2003: Chronological constraints on Variscan, Permian-Triassic and eo-Alpine (Cretaceous) evolution of the Great Hungarian Plain basement. - Geologica Carpathica 54/5, 299-315.

Lelkes-Felvári, Gy., Schuster, R., Frank, W. \& SASsi, R. 2005: Metamorphic history of the Algyő High, Tisza Mega-unit, basement of the Great Hungarian Plain - a counterpart of crystalline units of the Koralpe-Wölz nappe system (Austroalpine, Eastern Alps). Acta Geologica Hungarica 48/4, 371-394. https://doi.org/10.1556/ageol.48.2005.4.2

LIEBERMAN, J. \& PETRAKAKIS, K. 1991: TWEEQU thermobarometry: Analysis of uncertainties and application to granulites from western Alaska and Austria. - Canadian Mineralogist 29, 857-887.

M. То́тн T. 2008: Repedezett, metamorf fluidumtárolók az Alföld aljzatában. - Kézirat, MTA Doktori értekezés 399 p.

M. Tóth, T. \& SCHUBERT, F. 2018: Evolution of the Körös Complex orthogneiss, Tisza Megaunit, SE Hungary. - Journal of Geosciences 63, 21-46. https://doi.org/10.3190/jgeosci.253

M. Tóth, T. \& VARGÁNÉ Tóth, I. 2020: Lithologically controlled behaviour of the Dorozsma metamorphic hydrocarbon reservoir (Pannonian Basin, SE Hungary). - Journal of Petroleum Science and Engineering 195, 107748. https://doi.org/10.1016/ j.petrol.2020.107748

M. Tóth, T. \& ZACHAR, J. 2006: Petrology and deformation history of the metamorphic basement in the Mezősas-Furta crystalline high (SE Hungary). - Acta Geologica Hungarica 49/2, 165-188. https://doi.org/10.1556/ageol.49.2006.2.4

M. Tóth, T., Schubert, F. \& Zachar, J. 2000: Neogene exhumation of the Variscan Szeghalom dome, Pannonian Basin, E. Hungary. Geological Journal 35/3-4, 265-284. https://doi.org/10.1002/gj.861

M. Tóth T., Kedves M. \& Schubert F. 2003: Az Alföld metamorf aljzatának exhumációja a Szeghalom-dóm területén: Palinológiai bizonyítékok. - Földtani Közlöny 133/4, 547-562. 
M. Tóth T., Redlerné TÁtrai M. \& Kummer I. 2008: A Szeghalom környéki metamorf aljzat kiemelkedés szerkezetfejlődése és felépítése kőzettani és szeizmikus adatok alapján. - Magyar Geofizika 49/4, 143-151.

M. Tóth T., NAGY Á., VÁSÁRHelYi B., VÁN P. \& FöldES T. 2011: Repedezett tároló modellezés; kőzetmechanikai modell-kísérletek és szeizmikus attribútum alapú modellek korrelációja. V. Kömpöc, Csólyospálos-K. - Kézirat, MOL Nyrt., 66 p.

MANDELBRot, B. B. 1967: How long is the coast of Britain? Statistical self-similarity and fractional dimension. - Science 156, 636-638. https://doi.org/10.1126/science.156.3775.636

MAssone, H. J. \& SCHREYER, W. 1987: Phengite geobarometry based on limiting assemblage with K-feldspar, phlogopite and quartz. Contributions to Mineralogy and Petrology 96, 212-224. https://doi.org/10.1007/bf00375235

Masuda, T. \& FuJimURA, A. 1981: Microstructural development of fine-quartz aggregates by syntectonic recrystallization. - Tectonophysics 72, 105-128. https://doi.org/10.1016/0040-1951(81)90089-5

MeszéNA B. 1973: Az öttömösi szénhidrogén-kutatási terület földtani felépítése. - OGIL Müszaki Tudományok Közleményei 10, $25-35$.

Meyre, C., DE CAPITANI, C. \& PARTZSCH, J. H. 1997: A ternary solid solution model for omphacite and its application to geothermobarometry of eclogites from the Middle Adula nappe (Central Alps, Switzerland). - Journal of Metamorphic Geology 15, 687-700. https://doi.org/10.1111/j.1525-1314.1997.00042.x

Molnár, L., M. Tóth, T. \& Schubert, F. 2015: Structural controls on the petroleum migration and entrapment within faulted basement blocks of the Szeghalom Dome (Pannonian Basin, SE Hungary). - Geologia Croatica 68/3, 247-259. https://doi.org/10.4154/ gc.2015.19

PÁl-Molnár, E., Lelkes-Felvári, Gy., BatKi, A. \& SASSI, R. 2005: Metamorphic petrology and geochemistry of the Sarkadkeresztúr Basement-High with special regard to orthogneiss (Tisza Mega-unit, SE Hungary). - Acta Geologica Hungarica 48/4, 395-418. https://doi.org/10.1556/ageol.48.2005.4.3

PanĂ, D. I., Heaman, L. M., Creaser, R. A. \& Erdmer, P. 2002: Pre-Alpine Crust in the Apuseni Mountains, Romania: Insights from Sm-Nd and U-Pb Data. - Journal of Geology 110, 341-354. https://doi.org/10.1086/339536

PAP S. 1990: Felpikkelyezett rétegsorok a Közép-Tiszántúlon. - A Magyar Állami Földtani Intézet alkalmi kiadványa, Budapest, 36 p.

PAPP G. 2019: A szanki kristályos aljzat metamorf fejlődéstörténete. - Kézirat, Diplomamunka, SZTE, 51 p.

PAPP, N., VARGA, A., MÉSZÁros, E. \& RAUCSIK, B. 2017: Petrographic analyses of marbles: characteristic features of deformation and fluid-related effects in the Dorozsma marble (Tisza Mega Unit, South Hungary. (In Hungarian with English abstract.) - Földtani Közlöny 147/4, 337-356. https://doi.org/10.23928/foldt.kozl.2017.147.4.337

Passchier, C. W. \& Trouw, R. A. J. 2005: Microtectonics. - Springer, 366 p. https://doi.org/10.1007/978-3-662-08734-3

PLYUSNINA, L. P. 1982: Geothermometry and geobarometry of plagioclase-hornblende bearing assemblages. - Contributions to Mineralogy and Petrology 80, 140-146. https://doi.org/10.1007/bf00374891

Posgay, K., Takács, E., Szalai, I., Bodoky, T., Hegedứs, E., Jánváriné, K. I., TímÁr, Z., Varga, G., Bérczi, I. \& SZALAy, Á. 1996: International deep reflection survey along the Hungarian Geotraverse. - Geophysical Transactions 40/1-2, 1-44.

Powell, R. 1985: Regression diagnostics and robust regression in geothermometer/ geobarometer calibration: the garnet-clinopyroxene geothermometer revisited. - Journal of Metamorphic Geology 3, 231-243. https://doi.org/10.1111/j.1525-1314.1985.tb00319.x

Powell, R. \& Holland, T. J. B. 1985: An internally consistent thermodynamic dataset with uncertainties and correlations; I, Methods and a worked example. - Journal of Metamorphic Geology 3, 327-342. https://doi.org/10.1111/j.1525-1314.1985.tb00324.x

RAHL, J., ANDERSON, K., BRANDON, M. \& FASSOULAS, C. 2005: Raman spectroscopic carbonaceous material thermometry of low-grade metamorphic rocks: Calibration and application to tectonic exhumation in Crete, Greece. - Earth and Planetary Science Letters 240/2, 339-354. https://doi.org/10.1016/j.epsl.2005.09.055

Reiser, M. K., SchUster, R., SPIKINGS, R., TropPer, P. \& FüGENSChUH, B. 2017a: From nappe stacking to exhumation: Cretaceous tectonics in the Apuseni Mountains (Romania). - International Journal of Earth Sciences 106, 659-685. https://doi.org/10.1007/s00531-016-1335-y

Reiser, M. K., Schuster, R., Tropper, P. \& FÜgenschuh, B. 2017b: Constraints on the depositional and tectonometamorphic evolution of marbles from the Biharia Nappe System (Apuseni Mountains, Romania). - Geologica Carpathica 68/2, 147-164. https://doi.org/ 10.1515/geoca-2017-0012

Schubert, F., DiAmond, L. W. \& M. Tóth, T. 2007: Fluid inclusion evidence of petroleum migration through a buried metamorphic dome in the Pannonian Basin, Hungary. - Chemical Geology 244/3-4, 357-381. https://doi.org/10.1016/j.chemgeo.2007.05.019

SPRY, A. 1969: Metamorphic textures. - Pergamon Press, 350 p.

StegenA, L. 1964: The structure of the Earth's crust in Hungary. - Acta Geologica Academiae Scientiarum Hungaricae 8/1-4, 413-431.

SZEDERKÉNYI, T. 1984: Az Alföld kristályos aljzata és földtani kapcsolatai. - Kézirat, MTA Doktori értekezés. 326 p.

SZEDERKÉNYI, T., ÁRKAI, P. \& LELKES-FELVÁRI, Gy. 1991: Crystalline groundfloor of the Great Hungarian Plain and South Transdanubia. In: Karamata, S. (ed.): Geodynamic evolution of the Pannonian Basin. Beograd, 261-273.

SzEPESHÁZY K. 1966: A kristályos aljzat fontosabb kőzettípusai a Duna-Tisza köze középső és déli részén. - A Magyar Állami Földtani Intézet Évi Jelentése 1966-ról, 257-289.

SzEPESHÁZY K. 1971: Kőzettani adatok a Közép-Tiszántúl kristályos aljzatának ismeretéhez. A - A Magyar Állami Földtani Intézet Évi Jelentése 1971-ról, 141-168.

SzEPESHÁZY K. 1973a: A Duna-Tisza köze déli részének metamorf kőzetei. - A Magyar Állami Földtani Intézet Évi Jelentése 1973. évrôl, $147-166$.

SZEPESHÁZY K. 1973b: A Kárpátok és az Alföld metamorf képződményeinek kapcsolatai. - Általános Földtani Szemle 3, 5-57.

SzEPESHÁzy K. 1979: A Tiszántúlés azErdélyi-középhegység (Muntii Apuseni) nagyszerkezeti és rétegtani kapcsolatai.-Általános Földtani Szemle 12, 121-198.

SzILI-GYÉMÁNT, P. 1986: Metamorphic formations in Tiszántúl: the Körös-Berettyó and the Álmosd Units. - Acta Geologica Hugarica 29/3-4, 305-316. 
TAKAhashi, M., NAgAhama, H., MasudA, T. \& FujimuRA, A. 1998: Fractal analysis of experimentally, dynamically recrystallized quartz grains and its possible application as a strain rate meter. - Journal of Structural Geology 20/2-3, 269-275. https://doi.org/10.1016/ S0191-8141(97)00072-2

Tari, G., Horváth, F. \& Rumpler, J. 1992: Styles of extension in the Pannonian Basin. - Tectonophysics 208/1-3, 203-219. https://doi.org/10.1016/0040-1951(92)90345-7

Tari, G., Dövényi, P., Dunkl, I., Horváth, F., Lenkey, L., Stefanescu, M., Szafián, P. \& Tóth, T. 1999: Lithospheric structure of the Pannonian basin derived from seismic, gravity and geothermal data. - In: Durand, B., Jolivet, L., Horváth, F. \& SÉRAnNe, M. (eds): The Mediterranean Basins: Tertiary Extension within the Alpine Orogen. Geological Society, London, Special Publications 156, 215-250. https://doi.org/10.1144/GSL.SP.1999.156.01.12

Tuinstra, F. \& KoEnIG, J. L. 1970: Raman spectrum of graphite. - Journal of Chemical Physics 53, 1126-1130. https://doi.org/10.1063/ 1.1674108

VoLL, G. 1980: Ein Querprofil durch die Schweizer Alpen vom Vierwaldstatter See zur Wurzelzone-Strukturen und ihre Entwicklung durch Defomationsmechanismen wichtiger Minerale. - Neues Jahrbuch für Geologie und Paläontologie, Abhandlungen 160, 321335.

WATERS, D. J. \& MARTIN, H. N. 1993: Geobarometry of phengite-bearing eclogites. - Terra Abstracts 5, 410-411.

White, S. H., Burrows, S. E., Carreras, J., Shaw, N. D. \& HumphreYs, F. J. 1980: On mylonites in ductile shear zones. - Journal of Structural Geology 2, 175-187.

Whitney, D. L. \& Evans, B. W. 2010: Abbreviations for names of rock-forming minerals. - American Mineralogist 95, $185-187$. https://doi.org/10.2138/am.2010.3371

Wiederkehr, M., Bousquet, R., Ziemann, M. A., Berger, A. \& Schmid, S. M. 2011: 3-D assessment of peak-metamorphic conditions by Raman spectroscopy of carbonaceous material: an example from the margin of the Lepontine dome (Swiss Central Alps). International Journal of Earth Sciences (Geologische Rundschau) 100/5, 1029-1063. https://doi.org/10.1007/s00531-010-0622-2

WopenKa, B. \& PASTERIS, J. D. 1993: Structural characterization of kerogens to granulite-facies graphite: Applicability of Raman microprobe spectroscopy. - American Mineralogist 78, 533-557.

YUI, T. F., HuANG, E. \& XU, J. 1996: Raman spectrum of carbonaceous material: a possible metamorphic grade indicator for low-grade metamorphic rocks. - Journal of Metamorphic Geology 14, 115-124. https://doi.org/10.1046/j.1525-1314.1996.05792.x

Zachar J. 2008: A Jánoshalma ortogneisz blokk kőzettani felépítése, fejlődéstörténete és korrelációs lehetôségei. - Kézirat, PhD értekezés, Szegedi Tudományegyetem, 144 p.

ZACHAR, J. \& M. Tóth, T. 2004: Petrology of the metamorphic basement of the Tisza Block at the Jánoshalma high, S Hungary. - Acta Geologica Hungarica 47/4, 349-371. https://doi.org/10.1556/ageol.47.2004.4.3

ZaCHAR J. \& M. TóTH T. 2009: A Jánoshalma eklogit petrológiája. - In: M. TóTH T. (szerk.): Magmás és metamorf képzódmények a Tiszai Egységben. Geolitera, 117-144.

ZACHAR, J., M. Tóth, T. \& JANÁK, M. 2007: Kyanite eclogite xenolith from the orthogneiss terrane of the Tisza Megaunit, Jánoshalma area, crystalline basement of southern Hungary. - Lithos 99/3-4, 249-265. https://doi.org/10.1016/j.lithos.2007.06.001

Kézirat beérkezett: 2020. 10. 22. 